\section{CHANGES IN CROPPING \\ PATTERN IN ODISHA \\ AGRICULTURE IN NEO-LIBERAL PERIOD}

Falguni Pattanaik* and

SarbeswarMohanty**

\begin{abstract}
Role of agriculture remains vital in enabling the State to attain and maintain food self-sufficiency, especially, in a poverty-stricken State like Odisha. Despite the changes in the macroeconomic policy framework in the neo-liberal period, the agricultural sector in Odish a neither experienced any significant growth subsequent to the initiation of economic reforms in 1991 nor it derived the expected shift in cropping pattern. Sustainable growth of agriculture depends significantly on the process of agricultural transformation, which in turn is well connected with shifts in cropping patterns. The paper discusses the cropping pattern changes that have taken place in area allocation as well as in terms of production and productivity of major crop groups at the State level and across physiographic zones of the State. It is observed that there are variations in the share of area, production and productivity of major crop groups over the time at the State level and as well as across the physiographic zones. Sluggish shift in the cropping pattern towards non-foodgrain crops in the State is because of slow expansion of irrigation, low level of fertiliser consumption, slow technology adoption and low level of infrastructure. The slowdown in the process of cropping pattern change means that most government efforts to diversify agriculture have failed to take off.
\end{abstract}

\section{Introduction}

The degree, allocation and utilisation of land are factors that have long been recognised as fundamental factors for agricultural development and poverty reduction (Malthus, 1798; Ruthenberg, 1980). Composition of cropping pattern of agriculture in a particular country or region of the world tends to change over time and space. Agriculture isan inherently spatial process, with

*Assistant Professor (Economics), Department of Humanities and Social Sciences, IIT Roorkee, Roorkee, Email:falgunipattanaik@gmail.com.

**Assistant Professor (Economics), School of Humanities, KIIT University, Bhubaneswar, E-mail: smohantyfhu@kiit.ac.in. 
yields being greatly influenced by local factors such as climate and weather, soil type, temperature, and topography (Alexandratos and Bruinsma, 2012). Accordingly, agricultural production and productivity are perceptive to spatial and inter-temporal variations. Sustainable growth of agriculture depends significantly on the process of agricultural transformation, which in turn is well connected with shifts in cropping patterns (Rahman, 2009). In recent years, the growing demand for agricultural production has forced the farmers to ad opt intensification of agriculture practices along with the increased use of high-yielding crop varieties for maintaining higher levels of production (Weinberger and Lumpkin, 2007).

India made remarkable progress in the agricultural sector over the last five decades. From 'hand to mouth' situation in the early sixties, the country not only became selfreliant in foodgrains but also got sufficient resilience to tide over adverse conditions (Hazra, 2001). India's agriculture passed through four distinct phases of strategy. First, starting with the intensification of efforts in identified areas, using traditional technology and expansion of area during the pre-green revolution period. Second, use of modern inputs and high-yielding varieties in irrigated areas during the late sixties and the seventies (Green Revolution). Third, focus was on infrastructure including irrigation, research, extension, provision of agricultural inputs in eighties. And fourth, era of liberalisation and relaxation of controls during the nineties (postreforms period).As a result, although country's agriculture gained in strength and resilience over the years, growth in agriculture is highly skewed across some States and few crops (Bhalla and Singh, 2009). Odisha is one such State, which also experienced similar kind of development in the agricultural sector over the last five decades as the nation did. Being one of the poorest States of the country agriculture occupies the centre stage in the overall development of Odisha's economy. Nearly 84 per cent of Odisha's population lives in rural areas. Agriculture remains the mainstay of the State's economy and a major source of livelihood for a large majority of population (Mishra,2009).Agriculture in Odisha continues to provide employment to more than 60 per cent of the total workforce. However, over the years, in line with the trends in rest of the economy, share of agriculture to the Gross State Domestic Product (GSDP) recorded a substantial decline. In the 1950s, the share of agriculture to GSDP was about 70 per cent, which came down to skimpy less than 20 per cent in 2009-10 (at constant prices 1999-2000), (Government of Odisha, Economic Survey, 2011-12). The nature and extent of variability in the cropping pattern, its sources and implications, however, did not receive systematic attention till recently, at any rate in Odisha.

Quite a few researchers tried to study the changes in the cropping pattern of Odisha's agriculture at the State level as well as at the physiographic zone level. Therefore, the objective of this study is to examine area, production and productivity performance of 
major crop groups- how they change over time-giving more explicit attention to the spatial dimensions of Odisha agriculture. The present study also analyses the relationship, if any, between the levels and growth of agricultural output and the use of modern inputs like irrigation, fertilisers, etc. The study finds that there are variations in the share of area, production and productivity of major crop groups over the time period at the State level as well as across the physiographic zones. However, major changes in area allocation to different crops have not taken place during the study period. The process of diversification in cropping pattern from foodgrains to nonfoodgrains is very slow both in terms of production and productivity of the major crop groups. Sluggish shift in the cropping pattern towards non-foodgrain crops in the State is because of slow expansion of irrigation, low level of fertiliser consumption, slow technology adoption, and low level of infrastructure.Given the challenges agriculture in Odisha is faced with market-oriented approach and failed to bring in crop diversification.

\section{Agriculture in Odisha: A Historical Account}

Agriculture played an important role in the development process of Odisha and also the focus of the planners and policy makers changed from time to time towards the development of this sector. During pre-green revolution period (1950-1965) emphasis was on to increase production of foodgrain crops through double cropping, distribution of improved quality seeds, emphasis on green manuring, composting and increased consumption of fertilisers (Vyas, 1996). However, during the green revolution period (1965-1980), the objective was to increase the foodgrain crops through strategising for optimum cropping pattern under HYV programme, agriculture information service and provision of long-term credit facility (Rao, 1996). In the early 80s (post-green revolution period/ pre-economic reform period: 19801991), efforts were made to bring convergence between agricultural development programmes and poverty alleviation programme (Chand, 2003). During this period some new heads were added to the agriculture sector such as food storage and warehousing, agriculture research and education. In the name of New Economic Reforms (1991) a structural change took place at the national as well as at State level. However, during the posteconomic reform period (1991-onwards), the issues were to raise the productivity, increase the cultivable area of pulses and commercial crops, effective utilisation of irrigation facility and development of rural market for the improvement of the agriculture (Mishra and Chand, 1995; Chand, 2001). Other issues such as mechanisation of agriculture, development of agro-based industries, promoting private enterprises in marketing of agricultural products were also emphasised. To realise the objectives, target was to intervene in the areas of seed, fertiliser, farm mechanisation, commercial crops, credit and reclamation of problematic soils. Further, it was also targeted to mechanise the farm sector through provision of updated technological 
machineries. To strengthen the economic conditions of the farmers, an attempt was made to diversify the cropping pattern through introduction of commercial crops. In addition, it was also proposed to encourage contract farming, agri-business houses and consortia (Chand, 2003).

Due to diverse agro-climatic conditions in the State, a varied number of crops are produced and can beclassified into two groups - foodgrains and non-foodgrains. Due to the challenge of feeding large population around 75 per cent of the total cultivated area is under foodgrain (cereals and pulses). Changes in the cropping pattern in Odisha are generally viewed as a shift from traditionally grown less remunerative crops to more remunerative crops (Mohanty et al., 2013). Changes in the cropping pattern take place due to distinct soil problems, market infrastructure and governmental policies and thrust on some crops in a given time. During the period of green revolution, with the introduction of modern agricultural technology, there is a continuous surge for diversifying agriculture in terms of crops, primarily on economic considerations (J oshi at al., 2006). The cropping pattern changes, however, are the outcome of the interactive effect of many factors like resource related factors (irrigation, rainfall and soil fertility), technology related factors (seed, fertiliser, and storage and processing), institutional and infrastructure related factors (farm size, extension, marketing systems, investment, output and input prices, government regulatory policies, and research). Odisha agriculture has experienced the change in the relative importance of these factors over time. Furthermore, agricultural liberalisation and globalisation policies are also determining crop composition both at the micro and macro levels (Vyas, 2001).

As economic reforms are said to have brought about a clear shift in the focus on growth strategy, it may be useful to analyse the scenario of cropping pattern in the State during this neo-liberal reforms period. The present study aims at examining the cropping pattern in Odisha with respect to area, production and yield.

\section{Database and Methodology}

The study is based on secondary data. The data have been collected from various issues of Odisha Agriculture Statistics published by Directorate of Agriculture and Food Production, Odisha. Crop group-wise distribution of area to total area, yield to total yield and production to total production are discussed to understand the changes that have taken place over time. Triennium Ending (TE) data (1993/94 - 1995/96) to TE (2008/09 - 2010/ 11) have been considered to understand the pace of changes. The State has been divided into four physiographic zones as there are vast variations in agro-climatic conditions. A zonewise analysis has been undertaken on the basis of 30 districts (Table 1 ). 
Table 1: Division of Districts According to Physiographic Conditions

\begin{tabular}{|c|c|c|c|c|}
\hline & $\begin{array}{c}\text { Northern } \\
\text { Plateau (NP) }\end{array}$ & $\begin{array}{l}\text { Central Table } \\
\text { Land (CTL) }\end{array}$ & $\begin{array}{l}\text { Eastern } \\
\text { Ghat(EG) }\end{array}$ & $\begin{array}{c}\text { Coastal } \\
\text { Plains(CP) }\end{array}$ \\
\hline \multirow{2}{*}{ 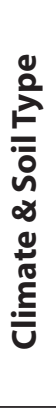 } & $\begin{array}{c}\text { Climate: mostly hot } \\
\& \text { moist and sub- } \\
\text { humid }\end{array}$ & $\begin{array}{c}\text { Climate: mostly hot } \\
\& \text { moist and sub- } \\
\text { humid }\end{array}$ & $\begin{array}{c}\text { Climate: have hot } \\
\text { and moist, sub- } \\
\text { humid, warm and } \\
\text { humid }\end{array}$ & $\begin{array}{c}\text { Climate: includes } \\
\text { moist } \& \text { sub-humid, } \\
\text { hot } \& \text { moist, hot } \& \\
\text { humid }\end{array}$ \\
\hline & $\begin{array}{l}\text { lateritic, red \& } \\
\text { yellow, red \& brown, } \\
\text { mixed red \& black }\end{array}$ & $\begin{array}{c}\text { from red \& yellow, } \\
\text { red } \& \text { black, black, } \\
\text { brown forest and } \\
\text { lateritic }\end{array}$ & $\begin{array}{c}\text { Soil types: red, } \\
\text { mixed red \& black, } \\
\text { black,lateritic, } \\
\text { alluvial }\end{array}$ & $\begin{array}{l}\text { Soil types:red, } \\
\text { deltaic,lateritic, } \\
\text { deltaic alluvial, } \\
\text { coastal alluvial, } \\
\text { saline } \\
\end{array}$ \\
\hline 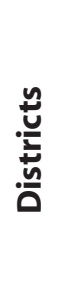 & $\begin{array}{l}\text { Keonjhar, } \\
\text { Mayurbhanj, } \\
\text { J harsuguda, } \\
\text { Sundargarh }\end{array}$ & $\begin{array}{c}\text { Bolangir, Sonepur } \\
\text { Dhenkanal, Angul } \\
\text { Sambalpur, Bargarh } \\
\text { Deogarh }\end{array}$ & $\begin{array}{l}\text { Kalahandi, Nuapara } \\
\text { Koraput, Malkangiri } \\
\text { Nawarangpur, } \\
\text { Rayagada, } \\
\text { Kandhamal, } \\
\text { Boudh }\end{array}$ & $\begin{array}{c}\text { Balaso re, Bhadrak, } \\
\text { Cuttack, } \\
\text { Jagatsinghpur, } \\
\text { Jajpur,Kendrapara, } \\
\text { Ganjam, Gajapati, } \\
\text { Puri } \\
\text { Khurda, Nayagarh }\end{array}$ \\
\hline
\end{tabular}

Source: Economic Survey of Odisha-2011-12.

Cropping Pattern Changes: A State Level Analysis

Measuring changes in the share of area, production and yield at the State level across crop groups explains the cropping patterns that are predominant in Odisha under the neo-liberal period. The analysis indicates long-term changes in cropping pattern that have occurred with changes in socio-economic conditions and macroeconomic environment with respect to food security, policy support and incentives and farmers' preference in response to market demands in the State.

\section{Temporal Changes in the Share of Area under Major Crops}

The share of area for major crop groups to gross cropped area in the State is considered important as it indicates the changes in cultivated area that have occurred over the years. This is reflective of the relative share of area of major crop groups in GCA. Distribution of area to gross cropped area of the State for major crop groups is shown in Table2. A careful analysis of trends in area of production to GCA reveals that area under cereals has been reported 52.28 per cent during 1994-96, whereas it has sustained at 58.29 per cent and 58.87 per cent during TE 1997-99 and 2000-02, respectively,thereafter it has shown a declining trend. During TE 1994-96, share of pulses has been registered 22.41 per cent of the gross cropped area. It has remained almost stagnant over the next three triennium ending periods. The share of pulses has increased marginally 
after TE 2003-05. However, share of foodgrains has varied between 74.6 and 77.6 per cent to GCA during the study periods. A constant decline in the area share of oilseeds has been observed upto TE 2003-05. However a marginal increase at 5.4 per cent and 13.4 per cent has been recorded in the succeeding time periods. Area under fibers in the State has hovered around 1 per cent excluding TE 2003-05, when more than 3 per cent area has been used for cultivation of fibers. The percentage of area used for vegetables cultivation diverged between 5.31 to 8.62 per cent during the study period 1994-2011.Condiments and spices have not gained much importance with respect to area used over the years, as understood from the figures.

Table 2: Share of Area under Major Crops in Odisha (Percentage of GCA)

\begin{tabular}{cccccccc}
\hline Year & Cereals & Pulses & Foodgrains & Oil Seeds & Fibers & Vegetables $\begin{array}{c}\text { Condiments } \\
\& \text { Spices }\end{array}$ \\
\hline TE 2009-11 & 53.05 & 22.67 & 75.72 & 10.73 & 1.08 & 7.26 & 1.65 \\
TE 2006-08 & 54.64 & 21.60 & 76.25 & 9.29 & 1.10 & 7.32 & 1.63 \\
TE 2003-05 & 57.69 & 18.23 & 75.92 & 8.78 & 3.40 & 5.31 & 1.72 \\
TE 2000-02 & 58.87 & 18.76 & 77.64 & 9.49 & 1.17 & 5.51 & 1.77 \\
TE 1997-99 & 58.29 & 18.55 & 76.84 & 10.53 & 0.99 & 5.84 & 1.73 \\
TE 1994-96 & 52.28 & 22.41 & 74.68 & 11.74 & 0.77 & 8.62 & 1.86 \\
\hline
\end{tabular}

Source: Odisha Agriculture Statistics, Directorate of Agriculture and Food Production, Odisha.

From the above analysis it is observed that three-fourths of the area under cultivation is used for food grain (cereals and pulses) cultivation while one-fourth of the area is utilised for non-foodgrain cultivation. Under foodgrain, cereals occupy the centre stage and vegetables and oilseeds under non-foodgrain. The skewed distribution of area towards cereals may be because of adaptability to a wide range of land types (rain-fed uplands, medium lands and low lands irrigated khariff, irrigated rabi and under a wide range of climatic conditions) and water regimes including conditions of water stagnation where no other crop could possibly be grown. Again it is observed that a very low proportion of area is used for vegetable cultivation. This may be due to lack of adequate irrigation facilities and suitability of soil types for vegetable cultivation. 
Temporal Changes in the Share of Production of Major Crops

Study of production of major crops to the total production is crucial from the view point of understanding the contribution of different crop groups to agriculture sector and in turn to the GSDP of the State. An analysis of share of production showing the changes in cropping pattern is presented in Table 3. Share of cereal production in the State ranged between 38.21 and 49.15 per cent over the study periods. However, share of pulses production to total production in the State has not been appreciable as it ranged between 3 to 6 per cent, although a considerable proportion of GCA has been used for pulses production. In TE 1997-99 and TE 2000-02, both cereals and pulses production have been recorded high that added to foodgrains production at more than 54 per cent at the State level. During TE 1994-96, production of oilseeds has been 5.15 per cent of total production, thereafter it has shown a declining trend over the study periods. Production of fiber condiments and spices in the State has never been appealing. Production share of vegetables over the time periods has remained remarkable. It has become highest in TE 200305 at 51.76 per cent to the total production. It is interesting to note that, share of vegetable production to total production in Odisha is appreciable, although the share of area used varies between 5 to 8 per cent. Production share of oilseeds as compared to the area used has remained low. Production share of fibers and condiments and spices in the State has also remained unappealing over the study period.

Table 3: Share of Production of Major Crops in Odisha (Percentage of Total Production)

\begin{tabular}{cccccccc}
\hline Year & Cereals & Pulses & Foodgrains & Oilseeds & Fibers & Vegetables $\begin{array}{c}\text { Condiments } \\
\& \text { Spices }\end{array}$ \\
\hline TE 2009-11 & 41.45 & 5.29 & 46.74 & 3.52 & 2.20 & 45.64 & 1.90 \\
TE 2006-08 & 43.26 & 4.79 & 48.05 & 3.40 & 2.12 & 45.32 & 1.11 \\
TE 2003-05 & 38.21 & 3.78 & 41.99 & 2.95 & 1.84 & 51.76 & 1.31 \\
TE 2000-02 & 49.15 & 5.09 & 54.24 & 4.07 & 2.64 & 37.35 & 1.70 \\
TE 1997-99 & 48.98 & 5.41 & 54.39 & 4.30 & 3.04 & 36.58 & 1.68 \\
TE 1994-96 & 41.60 & 6.92 & 48.58 & 5.15 & 2.86 & 42.21 & 1.25 \\
\hline
\end{tabular}

Source: Odisha Agriculture Statistics, Directorate of Agriculture and Food Production, Odisha.

While analysing the share of production, it is observed that there is a balance distribution between foodgrain and non-food grain. However, major contribution of cereals and vegetables is observed under foodgrain and non-foodgrain category, respectively. Furthermore, while analysing the share of yield of major crop groups it is observed that, 
vegetables account for two-thirds and the rest one-third is distributed among other crop groups. It is worth noting that the share of yield of cereals, pulses and foodgrains has declined over consecutive four triennium ending periods. Yield of oilseeds and fibers has not remained attractive; on the other hand, vegetables have shown an excellent trend with respect to yield and some visibility has been marked in the yield of condiments and spices, compared to its area and production.

\section{Temporal Changes in the Yield Share of Major Crops}

Crop productivity, or crop yield, is one of the essential indicators for agricultural development and is normally expressed as kilograms $(\mathrm{kg}$ ) of product per hectare (ha). The share of yield rate of the major crop groups to the total yield rate of the agricultural output considered for study is shown in Table 4. It is interesting to note that yield share of cereals and pulses decreased over first four triennium ending periods till TE 2003-05. However, the yield share of cereals increased by 17.9 per cent and pulses by 12.9 per cent during TE 2006-08. Same trend has been observed for foodgrains. Yield share of oilseeds varied between 3.68 and 5.63 per cent in the State during study period. However, percentage of oilseeds yield to total yield recorded maximum in triennium ending period TE 1994-96. Fibers showed a low productivity in the State throughout the study period. Yield share of fibers to total yield remained below 4 percent in all the TE periods except TE 1997-99. Yield share of vegetables remained splendid over the years at the State level. It has more than 60 per cent through all the triennium ending periods. Although area and production of condiments and spices remained low, the share of yield remained satisfactory during the periods of analysis.

Table 4: Share of Yield of Major Crops in Odisha (Percentage of Total Yield)

\begin{tabular}{cccccccc}
\hline Year & Cereals & Pulses & Foodgrains & Oilseeds & Fibers & Vegetables $\begin{array}{c}\text { Condiments } \\
\& \text { Spices }\end{array}$ \\
\hline TE 2009-11 & 7.92 & 2.37 & 6.30 & 4.04 & 3.73 & 63.98 & 11.66 \\
TE 2006-08 & 8.54 & 2.39 & 6.80 & 3.95 & 3.75 & 67.18 & 7.38 \\
TE 2003-05 & 7.01 & 2.08 & 5.70 & 3.68 & 3.77 & 69.82 & 8.00 \\
TE 2000-02 & 8.01 & 2.59 & 6.69 & 4.07 & 3.90 & 65.73 & 9.01 \\
TE 1997-99 & 8.41 & 2.91 & 7.07 & 4.07 & 5.51 & 62.31 & 9.71 \\
TE 1994-96 & 10.23 & 4.00 & 8.36 & 5.63 & 0.05 & 63.07 & 8.66 \\
\hline
\end{tabular}

Source: Odisha Agriculture Statistics, Directorate of Agriculture and Food Production, Odisha.

Journal of Rural Development, Vol. 36, No. 1, January - March : 2017 
The production and productivity of major crops in the State, is observed low and skewed towards the traditional crops (cereals and vegetables), may be due to traditional farming practices, low use of yield raising inputs like HYV seeds, fertilisers, organic manures, uneconomic size of operational holdings, low capital formation and investment in agriculture, deficient rural infrastructure and extension services, inappropriate policy environment and mostly regional diversification.

\section{Cropping Pattern Changes in Share of Area, Production and Yield of Major Crops Across Physiographic Zones}

Odisha's agriculture is known for its diversity which is mainly the result of variations in resource endowments, climate, soil type, land fertility, rainfall, temperature, water resources, topography,technologyadoption, infrastructure, natural calamities, availability of inputs, marketing, irrigation facilities, farm mechanisation, cropping intensity, size of land holdings, locations, crop diversification and commercialisation of agriculture, farmers' indebtedness, migration, historical, institutional and socio-economic factors. As a result, agricultural sector has followed an uneven path and huge gaps have been there in production and productivity across different regions and districts of the State. Analysing cropping pattern with respect to area, production and yield across the physiographic zones of major crop groups will help to look into the trends at the disaggregate level and to develop decentralised development strategies to ensure inclusive growth in the State in the long-run.

\section{Changes in Share of Area under Major Crops Across Physiographic Zones: Analysis of} distribution of area under cultivation for major crop groups to GCA over time across the physiographic zones has been presented in Tables $5_{a}$ and $5_{b}$. In NP, relatively more percentage of area has been used for cereals in all time periods as compared to other physiographic zones and maximum 66.16 per cent recorded in this zone in TE 2000-02. Although, a decreasing trend has been observed between TE 1997-99 and TE 2009-11 for CTL, share of area to GCA remained high over the time period. The temporal behaviour of area used for the six time periods in EG reflects that area share for cereals has remained maximum at 55.76 per cent in TE 2000-02 and in rest of the time periods it has shown a valuable share at more than 50 per cent. For $\mathrm{CP}$, area share has been 53.19 per cent in TE 1994-96, increased by 11 per cent in TE 1997 99 and thereafter, a continual decline is observed. Furthermore, proportion of area under pulses is observed maximum in CP over all intervening time periods and across zones. In CTL area under pulses, cultivation has been decreasing till TE 2000-02 and a substantial increase has been noticed during the remaining periods. Similar trend has been observed for EG. It is observed that less percentage of area is used for pulses in NP as compared to other zones. The area share of foodgrains seems to have occupied the centre 
stage for cultivation for all the physiographic zones and not much change is observed over the time period.

Area share of oilseeds has shown little fluctuations over the years in NP, however it has been decreasing till TE2000-02 and a marginal improvement has been recorded consequently (Table 5 b $_{\mathrm{b}}$.For CTL and EG, area share of oilseeds has gone down till TE 2003-05, and then increased by 13.8 per cent for CTL and 2.8 per cent for EG. Very negligible proportion of area has been used for cultivation of fibers as revealed by zone-wise investigation except TE 2003-05. Area share of vegetables for NP was 10.07 per cent to GCA in TE 1994-96 and it has declined till TE 2003-05, however, the share has increased after TE 2003-05. In CTL, lesser area has been used for vegetables as compared to NP.In EG, area share in various time periods has remained lower when correlated with CP. No perceptible amount of area has been utilised for condiments and spices across the physiographic zones over the time period.

Table 5: Changes in Share of Area under Foodgrains Across Physiographic Zones (Percentage of GCA)

\begin{tabular}{|c|c|c|c|c|c|c|c|}
\hline & Zones & TE2009-11 & TE2006-08 & TE2003-05 & TE2000-02 & TE1997-99 & TE1994-96 \\
\hline \multirow{4}{*}{$\frac{\frac{u}{\pi}}{\frac{\mathbb{U}}{\mathbb{U}}}$} & NP & 58.18 & 60.27 & 63.26 & 66.16 & 63.74 & 57.96 \\
\hline & CTL & 49.74 & 52.01 & 56.22 & 56.29 & 56.38 & 50.53 \\
\hline & EG & 50.31 & 51.67 & 55.54 & 55.76 & 54.63 & 50.35 \\
\hline & $\mathrm{CP}$ & 53.08 & 54.50 & 56.20 & 59.38 & 59.97 & 53.19 \\
\hline \multirow{4}{*}{$\begin{array}{l}\frac{\mathscr{y}}{2} \\
\frac{\omega}{2}\end{array}$} & NP & 16.40 & 15.35 & 13.25 & 12.20 & 13.79 & 15.91 \\
\hline & CTL & 23.76 & 22.51 & 19.28 & 18.28 & 18.97 & 21.75 \\
\hline & EG & 20.87 & 20.38 & 15.76 & 17.51 & 18.29 & 22.51 \\
\hline & $\mathrm{CP}$ & 24.52 & 23.42 & 20.34 & 21.21 & 19.27 & 23.81 \\
\hline \multirow{4}{*}{$\begin{array}{l}\frac{\text { }}{\overline{0}} \\
\frac{0}{0} \\
\frac{0}{0} \\
\frac{0}{4}\end{array}$} & NP & 74.58 & 75.62 & 76.51 & 78.35 & 77.54 & 73.87 \\
\hline & CTL & 73.50 & 74.52 & 75.50 & 74.57 & 75.35 & 72.27 \\
\hline & EG & 71.18 & 72.05 & 71.30 & 73.28 & 72.92 & 72.81 \\
\hline & $\mathrm{CP}$ & 77.60 & 77.92 & 76.54 & 80.59 & 79.24 & 77.00 \\
\hline
\end{tabular}

Source: Odisha Agriculture Statistics, Directorate of Agriculture and Food Production, Odisha. 
Table $5_{b}$ : Changes in Share of Area under Non-foodgrains Across

Physiographic Zones (Percentage of GCA)

\begin{tabular}{|c|c|c|c|c|c|c|c|}
\hline & Zones & TE2009-11 & TE2006-08 & TE2003-05 & TE2000-02 & TE1997-99 & TE1994-96 \\
\hline \multirow{4}{*}{$\begin{array}{l}\frac{n}{8} \\
\mathbb{U} \\
\stackrel{\omega}{\overline{0}}\end{array}$} & NP & 9.77 & 9.47 & 8.17 & 8.14 & 9.41 & 10.68 \\
\hline & CTL & 11.76 & 12.86 & 11.08 & 11.33 & 12.94 & 14.17 \\
\hline & EG & 11.22 & 11.78 & 11.45 & 12.46 & 14.56 & 15.35 \\
\hline & $\mathrm{CP}$ & 6.00 & 6.19 & 6.29 & 6.93 & 6.95 & 8.53 \\
\hline \multirow{4}{*}{$\frac{\frac{n}{2}}{\frac{0}{17}}$} & NP & 0.59 & 0.70 & 3.58 & 0.93 & 0.94 & 0.93 \\
\hline & CTL & 1.05 & 1.10 & 2.97 & 0.89 & 0.70 & 0.56 \\
\hline & EG & 1.37 & 1.41 & 3.77 & 1.57 & 1.31 & 0.72 \\
\hline & $\mathrm{CP}$ & 0.41 & 0.50 & 3.54 & 0.67 & 0.84 & 0.77 \\
\hline \multirow{4}{*}{$\begin{array}{l}\frac{y}{0} \\
\frac{1}{d} \\
\frac{d}{0} \\
\frac{d}{3}\end{array}$} & NP & 8.34 & 8.43 & 5.97 & 6.53 & 6.57 & 10.07 \\
\hline & CTL & 6.63 & 5.96 & 4.49 & 6.02 & 5.50 & 8.89 \\
\hline & EG & 7.20 & 7.37 & 5.39 & 5.50 & 4.89 & 6.86 \\
\hline & $\mathrm{CP}$ & 8.70 & 8.84 & 6.26 & 5.97 & 6.32 & 9.18 \\
\hline \multirow{4}{*}{ 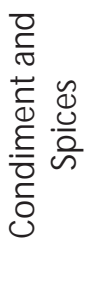 } & NP & 1.56 & 1.56 & 1.57 & 2.14 & 2.07 & 2.14 \\
\hline & CTL & 1.76 & 1.67 & 1.67 & 2.15 & 2.10 & 2.10 \\
\hline & EG & 2.37 & 2.24 & 2.43 & 2.47 & 2.36 & 2.19 \\
\hline & $\mathrm{CP}$ & 1.70 & 1.72 & 1.89 & 1.50 & 1.47 & 1.63 \\
\hline
\end{tabular}

Source: Odisha Agriculture Statistics, Directorate of Agriculture and Food Production, Odisha.

Changes in Share of Production of Major Crops Across Physiographic Zones:Zone-wise analysis of production share of major crop groups (foodgrains and non-foodgrains) in the State has been done to identify their relative importance in the cropping pattern and shown in Tables 6 and $6_{b}$. Cereal production has shown a continuous fluctuation among all the zones over the study period. Significant improvement is observed in production share of cereals across all the zones between TE 199496 and 1997-99. However, it has declined marginally except NP in TE 2000-02. But there is a significant decline in production share of cereals for all the zones in the TE 2003-05. However, production share of cereals has 
increased significantly in TE 2006-08 across all the zones. In TE 2009-11, production share of cereals has again declined for all the zones except EG. The production share of pulses has remained very low and it varied between 2 and 9 per cent across the physiographic zones during the study period.A continuous decline in the share of pulses production is observed for all the physiographic zones from TE 199496 to TE 2003-05 except in CP in TE 2000-02. However, there is an increase in the share of pulses production during the subsequent TE periods. Foodgrains consisting of cereals and pulses have shown fluctuations and similar kind of trend for all the zones.

Under non-foodgrains, the production share of oilseeds in the State is very low and it varied between 1.71 and 6.11 per cent across the physiographic zones during the study period. The share of oilseeds production has declined continuously for all the zones from TE 1994-96 to 2003-05 except CP in TE 2000-02. However, it has increased in the subsequent triennium periods except EG in 2009-11. The production share of fibers is extremely low across the physiographic zones. For NP, small increase has been observed between TE 199496 and TE 1997-99 and then it has declined continuously over the study period. In EG, the share of fiber production has shown a consistency and remained at more than 2 per cent throughout the study period. However, a continual decline has been recorded till TE 2003-05 and a marginal increase has been marked in TE 2006-08 in the CP zone.

Under non-foodgrains production, share of vegetables is predominant and occupies an important place in diversification of agriculture and plays a pivotal role for food and nutritional security. Significant decline is observed in the share of vegetable production across all the zones between TE 1994-96 and 1997-99. However, the share of vegetables production has increased significantly during TE2000-02 and TE 2003-05 across all the zones. But there is a significant decline in the share of vegetable production by more than 5 per cent for all the zones in the TE2006-08. Furthermore, the share of vegetable production has increased in TE 2009-11 across all the zones except EG.Although condiments and spices are important cash crops in Odisha, results indicate that physical production has not been remarkable to total agricultural production. The production share of condiments and spices in the State is very low and it varied between 0.96 to 3.87 percent across the physiographic zones during the study period. 
Table $6_{a}$ : Changes in Share of Production of Foodgrains Across Physiographic Zones (Percentage of Total Production)

\begin{tabular}{|c|c|c|c|c|c|c|c|}
\hline & Zones & TE2009-11 & TE2006-08 & TE2003-05 & TE2000-02 & TE1997-99 & TE1994-96 \\
\hline \multirow{4}{*}{$\begin{array}{l}\frac{n}{\mathbb{O}} \\
\frac{\mathbb{U}}{\mathbb{U}}\end{array}$} & NP & 33.96 & 44.38 & 37.21 & 47.57 & 45.27 & 40.58 \\
\hline & CTL & 43.13 & 49.77 & 43.92 & 46.07 & 48.32 & 41.19 \\
\hline & EG & 40.86 & 40.68 & 35.37 & 46.04 & 47.91 & 41.81 \\
\hline & $\mathrm{CP}$ & 38.88 & 39.62 & 35.23 & 46.96 & 50.44 & 42.89 \\
\hline \multirow{4}{*}{ 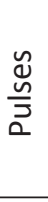 } & NP & 4.53 & 3.38 & 2.88 & 3.57 & 5.32 & 5.58 \\
\hline & CTL & 5.57 & 4.95 & 3.84 & 4.70 & 5.50 & 6.81 \\
\hline & EG & 5.70 & 5.80 & 3.94 & 5.40 & 5.51 & 8.77 \\
\hline & $\mathrm{CP}$ & 5.09 & 4.70 & 3.87 & 6.15 & 6.09 & 6.88 \\
\hline \multirow{4}{*}{ 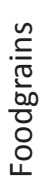 } & NP & 38.49 & 47.76 & 40.09 & 51.14 & 50.59 & 46.16 \\
\hline & CTL & 48.69 & 54.72 & 47.76 & 50.77 & 53.82 & 48.01 \\
\hline & EG & 46.55 & 46.48 & 39.31 & 51.43 & 53.43 & 50.58 \\
\hline & $\mathrm{CP}$ & 43.97 & 44.33 & 39.10 & 53.11 & 56.53 & 50.04 \\
\hline
\end{tabular}

Source: Odisha Agriculture Statistics, Directorate of Agriculture and Food Production, Odisha.

Table $6_{b}$ : Changes in Share of Production of Non-foodgrains Across Physiographic Zones (Percentage of Total Production)

\begin{tabular}{|c|c|c|c|c|c|c|c|}
\hline & Zones & TE2009-11 & TE2006-08 & TE2003-05 & TE2000-02 & TE1997-99 & TE1994-96 \\
\hline \multirow{4}{*}{ 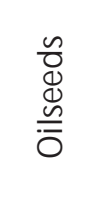 } & NP & 3.04 & 2.16 & 1.71 & 2.42 & 3.72 & 3.90 \\
\hline & CTL & 4.45 & 4.44 & 3.51 & 4.56 & 5.48 & 5.78 \\
\hline & EG & 3.91 & 4.00 & 3.40 & 4.55 & 5.22 & 6.11 \\
\hline & $\mathrm{CP}$ & 3.57 & 3.50 & 3.42 & 4.67 & 3.79 & 4.99 \\
\hline \multirow{4}{*}{$\begin{array}{l}\frac{n}{2} \\
\frac{0}{2}\end{array}$} & NP & 1.56 & 1.67 & 1.72 & 3.54 & 4.36 & 3.55 \\
\hline & CTL & 1.80 & 1.99 & 1.74 & 2.15 & 1.43 & 1.55 \\
\hline & EG & 2.52 & 2.43 & 2.35 & 2.46 & 2.89 & 2.21 \\
\hline & $\mathrm{CP}$ & 1.55 & 1.73 & 1.30 & 2.48 & 3.36 & 3.42 \\
\hline \multirow{4}{*}{$\begin{array}{l}\frac{y}{0} \\
\frac{0}{0} \\
\frac{1}{0} \\
\frac{8}{3}\end{array}$} & NP & 55.19 & 47.41 & 55.21 & 41.01 & 39.49 & 45.03 \\
\hline & CTL & 43.63 & 37.73 & 45.53 & 40.51 & 37.05 & 43.46 \\
\hline & EG & 43.14 & 45.33 & 52.79 & 38.58 & 35.42 & 38.84 \\
\hline & $\mathrm{CP}$ & 49.63 & 49.45 & 54.69 & 38.39 & 35.10 & 40.86 \\
\hline \multirow{4}{*}{ 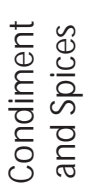 } & NP & 1.72 & 1.00 & 1.21 & 1.89 & 1.84 & 1.36 \\
\hline & CTL & 1.43 & 1.13 & 1.26 & 2.01 & 2.21 & 1.19 \\
\hline & EG & 3.87 & 1.75 & 2.07 & 2.96 & 3.04 & 2.25 \\
\hline & $\mathrm{CP}$ & 1.28 & 1.00 & 1.23 & 1.34 & 1.22 & 0.96 \\
\hline
\end{tabular}

Source: Odisha Agriculture Statistics, Directorate of Agriculture and Food Production, Odisha. 


\section{Changes in Share of Yield of Major Crops}

Across Physiographic Zones: Study regarding agricultural yield is essential to understand the pace of changes in output per hectare and changes in the cropping pattern. Tables $7_{\mathrm{a}}$ and $7_{b}$ indicate zone-wise yield share of foodgrains and non-foodgrains to the total yield. Continuous decline in yield share of cereals is observed from TE 1994-96 to 2003-05 across all the zones. However, yield share of cereals has increased significantly in the TE 2006-08 for all the zones and further it has declined except EG in TE 2009-11. The yield share of pulses has not been impressive at the State level as well as at the zonal level. It varied between 1.97 to 5.61 per cent across the zones during the study period. The yield share of pulses has remained highest in the first triennium ending period (TE 1994-96) in all the zones, except NP, where,5.61 per cent of yield share has been observed in TE 1997-99. A marginal increase has been seen in TE 2006-08 as compared to previous TE period across the zones. Again, a marginal increase has been recorded in NP and CTL in the last period (TE 2009-11). Similar trend has been observed for foodgrains across the zones. In TE 1994-96, yield share of foodgrains has remained highest as compared to other TE periods across the zones. Continuous decline in the share of yield of foodgrains is observed from TE 1994-96 to 2003-05 across all the zones, except in TE 2000-02 for EG. In TE 2009-11, a substantial decline in yield has been observed in NP and CTL and for EG and CP a moderate decline has been witnessed.
Under non-foodgrains, continuous decline in yield share of oilseeds is observed from TE 1994-96 to 2003-05 across all the zones. However, yield share of oilseeds has increased in the TE 2006-08 and TE 2009-11 for all the zones, but not significantly. Zone-wise, yield shares of fibers indicate that, share of yield of fibers in the CP and NP has remained higher as compared to other two zones during the study period. Yield share of fibers was negligible in TE 1994-96 for all the zones. However, a sudden rise in the share of yield has been observed in TE 1997-99 for all the zones among which NP reported maximum 7.34 per cent. The yield share of vegetables remained splendid over the years across the physiographic zones. In TE 2003-05, the share of yield of vegetables has been observed maximum for all the physiographic zones as compared to other TE periods. During this TE period in EG, the share reported maximum 71.61 per cent followed by 70.05 per cent in NP. There is a decline in the share of yield of vegetables observed during TE2006-08 across all the zones. During TE 200911 , share of yield of vegetables has increased marginally except EG and CP. A noticeable improvement has been observed in the yield share of condiments and spices between TE 1994-96 and 1997-99 across all the zones. On the other hand, a continuous decline in the share of yield of condiments and spices is observed from TE 2000-02 to TE 2006-08 for all the zones. However, significant increment is noticed in the recent TE 2009-11 for all zones where in EG the share reported maximum 11.56 per cent followed by 10.46 per cent in NP. 
Table 7 : Changes in Share of Yield of Foodgrains Across Physiographic Zones (Percentage of Total Yield)

\begin{tabular}{|c|c|c|c|c|c|c|c|}
\hline & Zones & TE2009-11 & TE2006-08 & TE2003-05 & TE2000-02 & TE1997-99 & TE1994-96 \\
\hline \multirow{4}{*}{$\begin{array}{l}\frac{v}{\sigma} \\
\frac{\mathscr{U}}{\mathbb{U}}\end{array}$} & NP & 5.89 & 8.30 & 6.49 & 7.20 & 7.17 & 9.78 \\
\hline & CTL & 8.45 & 9.79 & 7.66 & 8.24 & 8.55 & 10.61 \\
\hline & EG & 8.08 & 8.08 & 6.52 & 7.89 & 8.14 & 9.44 \\
\hline & $\mathrm{CP}$ & 7.94 & 8.28 & 7.13 & 7.65 & 9.00 & 11.06 \\
\hline \multirow{4}{*}{$\begin{array}{l}\frac{\tilde{y}}{J} \\
\frac{m}{2}\end{array}$} & NP & 2.69 & 2.51 & 2.34 & 2.75 & 5.61 & 4.73 \\
\hline & CTL & 2.33 & 2.27 & 1.97 & 2.40 & 2.86 & 3.92 \\
\hline & EG & 2.54 & 2.67 & 2.35 & 2.69 & 2.60 & 4.32 \\
\hline & $\mathrm{CP}$ & 2.26 & 2.30 & 2.14 & 2.57 & 3.16 & 4.05 \\
\hline \multirow{4}{*}{ 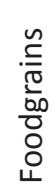 } & NP & 5.19 & 7.10 & 5.76 & 6.48 & 6.57 & 9.10 \\
\hline & CTL & 6.60 & 7.60 & 6.23 & 6.81 & 7.14 & 8.67 \\
\hline & EG & 6.52 & 6.62 & 5.60 & 6.68 & 6.60 & 8.09 \\
\hline & $\mathrm{CP}$ & 6.14 & 6.45 & 5.81 & 6.31 & 7.49 & 8.54 \\
\hline
\end{tabular}

Source: Odisha Agriculture Statistics, Directorate of Agriculture and Food Production, Odisha.

Table 7 ${ }_{b}$ : Changes in Share of Yield of Non-foodgrains Across Physiographic Zones (Percentage of Total Yield)

\begin{tabular}{|c|c|c|c|c|c|c|c|}
\hline & Zones & TE2009-11 & TE2006-08 & TE2003-05 & TE2000-02 & TE1997-99 & TE1994-96 \\
\hline \multirow{4}{*}{$\begin{array}{l}\frac{n}{0} \\
\frac{\mathscr{n}}{\overline{0}}\end{array}$} & $N P$ & 2.75 & 2.45 & 2.27 & 3.03 & 3.95 & 4.92 \\
\hline & CTL & 4.01 & 3.71 & 3.36 & 3.83 & 4.26 & 5.29 \\
\hline & EG & 3.19 & 3.24 & 2.73 & 3.35 & 3.14 & 4.61 \\
\hline & $\mathrm{CP}$ & 6.05 & 6.09 & 5.41 & 5.99 & 5.54 & 7.88 \\
\hline \multirow{4}{*}{$\begin{array}{l}\frac{n}{\tilde{d}} \\
\frac{0}{i}\end{array}$} & NP & 4.66 & 4.93 & 4.71 & 6.13 & 7.34 & 0.05 \\
\hline & CTL & 3.79 & 3.89 & 4.02 & 3.65 & 3.84 & 0.04 \\
\hline & EG & 3.86 & 3.75 & 3.31 & 2.92 & 3.63 & 0.03 \\
\hline & $\mathrm{CP}$ & 6.39 & 6.05 & 5.01 & 5.26 & 6.32 & 0.06 \\
\hline \multirow{4}{*}{$\begin{array}{l}\frac{y}{\frac{0}{0}} \\
\frac{d}{4} \\
\frac{8}{8}\end{array}$} & $N P$ & 68.37 & 67.25 & 70.05 & 65.42 & 60.02 & 62.32 \\
\hline & CTL & 67.21 & 66.03 & 69.49 & 67.08 & 63.63 & 64.39 \\
\hline & EG & 64.26 & 68.13 & 71.61 & 67.83 & 66.33 & 64.54 \\
\hline & $\mathrm{CP}$ & 63.11 & 64.39 & 67.45 & 63.97 & 59.96 & 60.14 \\
\hline \multirow{4}{*}{ 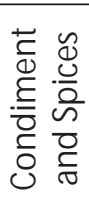 } & $N P$ & 10.46 & 7.46 & 8.37 & 8.99 & 9.33 & 9.10 \\
\hline & CTL & 7.61 & 6.71 & 7.27 & 7.98 & 9.73 & 7.08 \\
\hline & EG & 11.56 & 7.50 & 7.89 & 8.64 & 9.56 & 8.97 \\
\hline & $\mathrm{CP}$ & 8.11 & 6.43 & 7.05 & 8.26 & 8.53 & 8.28 \\
\hline
\end{tabular}

Source: Odisha Agriculture Statistics, Directorate of Agriculture and Food Production, Odisha. 
Determinants of Agricultural Production in Odisha

As it is observed from the above analysis, agriculture in the State has shown a high degree of disparity across the physiogrphic zones, therefore, it is, in this context, pertinent to examine the major determining factors of agricultural production and draw implications thereon. The study examines the impact of the factors considering foodgrains and non-foodgrains over the period 1993-94, 2001-02 and 2010-11. Detailed data on area, production and productivity is given in annexure (Table A1 to A8) for the respective time periods. Besides, an attempt is made to find out the impact of such determinants on total agricultural production (considering both foodgrains and non-food grains together) over the same periods.

\section{Hypotheses and Variables}

Changes in the crop sector are influenced by several factors such as the use of physical inputs, weather conditions, irrigation, credit availability, market, and government policies. This study examines the determinants of crop production at the State level through the neo-classical growth model, which is described as follows:

The aggregate production function can be specified as

$Y=f(R, G C A, C l, G I A, F C, L R)$

Where $Y$ is the aggregate crop productivity (foodgrains, non-foodgrains, total (foodgrains + non-foodgrains); $R$ is rainfall; $G C A$ gross cropped area; $C$ is cropping intensity; $G I A$ is the gross irrigated area; $F C$ is fertiliser consumption; and $L R$ is literacy rate.

Level of production generally determines the overall performance of an agrarian economy and treated as dependent variable in a broad analytical framework (Bhattacharya and Bhattacharya 2007). Consumption of fertilisers and cropping intensity are taken as the main technological variables. The rationale for including rainfall in the production function is that a significant proportion of cultivated area depends on rainfall and its variation affects the crop output substantially. Similarly, the gross cultivated area has shown very little fluctuations over time and it is taken as proxy for available land for cultivation. The gross irrigated area represents use of water from all sources of irrigation for crop production. Education has a significant impact upon agricultural productivity, which may boost farm productivity through refining the quality of labour, by increasing access to information and awareness programmes on agricultural practices. Thus, literacy rate is considered as an important variable in the study. Notwithstanding the limitations, the selected variables do have a good capacity to present the true picture of overall agricultural performance of the State.

On the basis of preceding discussion, the following hypotheses are thus formulated:

Journal of Rural Development, Vol. 36, No. 1, January - March : 2017 
$H(a)$ : Stable rainfall causes increase in agricultural productivity;

H (b): Greater the share of cultivable area to the total geographical area, the higher would be the overall agricultural productivity;

$\mathrm{H}$ (c): Cropping intensity is directly related to agricultural productivity;
$H(d)$ : Improved irrigational facilities lead to higher agricultural productivity;

$H(e)$ : Fertiliser consumption affects agricultural productivity;

$H(f)$ : Higher the literacy rate, higher is the agricultural productivity

The following section, accordingly, presents all the variables, dependent and independent, and indicates the methods of their measurement.

\begin{tabular}{llc}
\hline \multicolumn{1}{c}{ Variables } & \multicolumn{1}{c}{ Method of Measurement } & Notations \\
\hline $\begin{array}{l}\text { Agricultural Production } \\
\text { (Foodgrains, Non-Food } \\
\text { Grains, Total) }\end{array}$ & $\begin{array}{l}\text { Level of production in foodgrains, Non-foodgrains } \\
\text { Total (Foodgrains + Non-foodgrains) }\end{array}$ & $\mathrm{Y}$ \\
\hline Rainfall (R) & Actual rainfall as the ratio to normal rainfall & $\mathrm{X}_{1}$ \\
\hline $\begin{array}{l}\text { Gross Cultivable } \\
\text { Area (GCA) }\end{array}$ & $\begin{array}{l}\text { Gross cultivable area as a ratio to the total } \\
\text { geographical area }\end{array}$ & $\mathrm{X}_{2}$ \\
\hline Cropping Intensity (CI) & $\begin{array}{l}\text { The ratio of gross cultivable area to net cropped } \\
\text { area }\end{array}$ & $\mathrm{X}_{3}$ \\
\hline Irrigation (I) & $\begin{array}{l}\text { The gross irrigated area as a ratio to the gross } \\
\text { cropped area }\end{array}$ & $\mathrm{X}_{4}$ \\
\hline $\begin{array}{l}\text { Fertiliser Consumption } \\
\text { (FC) }\end{array}$ & $\begin{array}{l}\text { Total fertilisers consumed for crop production as } \\
\text { a ratio to the gross cropped area }\end{array}$ & $\mathrm{X}_{5}$ \\
\hline Literacy Rate (LR) & Literacy rate & $\mathrm{X}_{6}$ \\
\hline
\end{tabular}




\section{Model Specification}

With a view to examining the impact of macroeconomic factors on agricultural productivity in Odisha, the study is carried out with ordinary least squares (OLS) estimation of the multiple regression model with $k$ explanatory variables and specified.

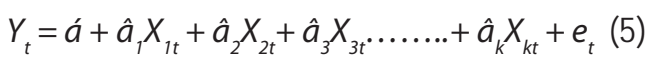

Where $X_{1 t}$ is the $t^{\text {th }}$ observation on the first explanatory variable (for $t=1 \ldots N$ observations)

All the variables are in logarithmic form and the model is estimated through the ordinary least squares (OLS) method. Empirical models are designed to ensure that the potential econometric problemsspecification bias and simultaneity-are taken into account. In order to test the robustness of the results, the regression analysis has been done for foodgrains, non-foodgrains and for total, taking both foodgrains and non-food grains into consideration for the year 2010-11, 2001-02 and 1993-94 at three different time periods and taking district as unit of study.

\section{Results and Discussion}

For present data set, $F$ test result suggests that OLS model is efficient. Thus, economic interpretation of the results is based on OLS model. Table 8 presents the results at the aggregate level considering both food grains and non-foodgrains and also independently foodgrains and non-foodgrains for the year 2010-11,2001-02 and 1993-94. The key variables of interest of this study are agricultural productivity and macroeconomic factors affecting agricultural production. The results regarding the effect of macroeconomic factors on foodgrains productivity are presented in column 2 of Table 8 for the year 2010-11.The coefficient of the macroeconomic factors i.e. rainfall, gross cropped area, gross irrigated area, fertiliser consumption, and literacy rate are positive and significant, except cropping intensity. For the year 2010-11 column 3 of Table 8 presents results regarding the effect of macroeconomic factors on levels of productivity of non-foodgrain crops and the coefficient of the macroeconomic factors i.e. rainfall, gross cropped area,cropping intensity, gross irrigated area, fertiliser consumption and literacy rate are positive and significant. Furthermore, the results regarding the effect of macroeconomic factors on aggregate agricultural productivity taking both food grains and non-foodgrains, are presented in column 4 of Table 8 for the year 2010-11. The coefficient of the macroeconomic factors i.e. rainfall, gross cropped area, cropping intensity, gross irrigated area, fertiliser consumption and literacy rate are positive and significant.Similar kind of results have been observed for the year 2001-02 and 1993-94. 
Table 8: Estimation of Relationship between Agricultural Productivity (Foodgrains and Non-Foodgrains) and Selected Macroeconomic Variables

\begin{tabular}{|c|c|c|c|c|c|c|c|c|c|}
\hline & \multicolumn{3}{|c|}{$\begin{array}{l}\text { Estimated Coefficients } \\
\qquad(2010-11)\end{array}$} & \multicolumn{3}{|c|}{$\begin{array}{l}\text { Estimated Coefficients } \\
\qquad(2001-02)\end{array}$} & \multicolumn{3}{|c|}{$\begin{array}{l}\text { Estimated Coefficients } \\
\qquad(1993-94)\end{array}$} \\
\hline 1 & 2 & 3 & 4 & 5 & 6 & 7 & 8 & 9 & 10 \\
\hline Variables & $\begin{array}{l}\text { Food- } \\
\text { grains }\end{array}$ & $\begin{array}{c}\text { Non- } \\
\text { foodgrains }\end{array}$ & Total & $\begin{array}{l}\text { Food- } \\
\text { grains }\end{array}$ & $\begin{array}{c}\text { Non- } \\
\text { foodgrains }\end{array}$ & Total & ood- & $\begin{array}{c}\text { Non- } \\
\text { foodgrains }\end{array}$ & Total \\
\hline$R$ & $\begin{array}{c}0.32 * * * \\
(4.78)\end{array}$ & $\begin{array}{c}0.35 * * * \\
(4.81)\end{array}$ & $\begin{array}{c}0.30 * * * \\
(4.75)\end{array}$ & $\begin{array}{c}0.28^{* * *} \\
(3.78)\end{array}$ & $\begin{array}{c}0.29 * * * \\
(3.81)\end{array}$ & $\begin{array}{c}0.27^{* * *} \\
(3.76)\end{array}$ & $\begin{array}{c}0.31 * * * \\
(4.58)\end{array}$ & $\begin{array}{c}0.28 * * * \\
(4.12)\end{array}$ & $\begin{array}{c}0.30 * * * \\
(4.48)\end{array}$ \\
\hline$G C A$ & $\begin{array}{l}0.035^{*} \\
(2.21)\end{array}$ & $\begin{array}{l}0.032 * \\
(2.21)\end{array}$ & & $\begin{array}{l}0.031^{*} \\
(2.20)\end{array}$ & $\begin{array}{l}0.021^{*} \\
(1.89)\end{array}$ & & $\begin{array}{l}0.019^{*} \\
(1.81)\end{array}$ & $\begin{array}{l}0.016 * \\
(1.78)\end{array}$ & $\begin{array}{l}0.018^{*} \\
(1.80)\end{array}$ \\
\hline $\mathrm{Cl}$ & $\begin{array}{c}0.01 \\
(0.76)\end{array}$ & $\begin{array}{l}0.21^{* *} \\
(2.76)\end{array}$ & $\begin{array}{l}0.11^{*} \\
(2.56)\end{array}$ & $\begin{array}{c}0.02 \\
(0.76)\end{array}$ & $\begin{array}{l}0.12 * * \\
(2.71)\end{array}$ & $\begin{array}{l}0.09 * * \\
(1.78)\end{array}$ & $\begin{array}{c}0.01 \\
(0.71)\end{array}$ & $\begin{array}{l}0.13^{* *} \\
(2.74)\end{array}$ & $\begin{array}{l}0.11^{* *} \\
(2.71)\end{array}$ \\
\hline$G I A$ & $\begin{array}{c}0.73 * * * \\
(2.04)\end{array}$ & $\begin{array}{c}0.63 * * * \\
(1.94)\end{array}$ & $\begin{array}{l}0.68^{* * *} \\
(1.84)\end{array}$ & $\begin{array}{c}0.71^{* * *} \\
(2.03)\end{array}$ & $\begin{array}{c}0.66 * * * \\
(1.93)\end{array}$ & $\begin{array}{c}0.69 * * * \\
(1.99)\end{array}$ & $\begin{array}{c}0.62 * * * \\
(1.91)\end{array}$ & $\begin{array}{l}0.73 * * * \\
(1.94)\end{array}$ & $\begin{array}{l}0.70^{* * *} \\
(1.97)\end{array}$ \\
\hline$F C$ & $\begin{array}{c}0.31 * * * \\
(2.39)\end{array}$ & $\begin{array}{c}0.30 * * * \\
(2.38)\end{array}$ & $\begin{array}{c}0.30^{* * *} \\
(2.39)\end{array}$ & $\begin{array}{c}0.21^{* * *} \\
(2.19)\end{array}$ & $\begin{array}{c}0.20 * * * \\
(2.09)\end{array}$ & $\begin{array}{c}0.20^{* * *} \\
(2.10)\end{array}$ & $\begin{array}{c}0.27 * * * \\
(2.11)\end{array}$ & $\begin{array}{l}0.47 * * * \\
(2.91)\end{array}$ & $\begin{array}{c}0.39 * * * \\
(2.81)\end{array}$ \\
\hline$L R$ & $\begin{array}{c}0.21 * * * \\
(2.49)\end{array}$ & $\begin{array}{c}0.29 * * * \\
(2.43)\end{array}$ & $\begin{array}{c}0.26^{* * *} \\
(2.45)\end{array}$ & $\begin{array}{c}0.18^{* * *} \\
(2.39)\end{array}$ & $\begin{array}{c}0.21^{* * *} \\
(2.40)\end{array}$ & $\begin{array}{c}0.20 * * * \\
(2.39)\end{array}$ & $\begin{array}{c}0.15 * * * \\
(2.12)\end{array}$ & $\begin{array}{c}0.18 * * * \\
(2.21)\end{array}$ & $\begin{array}{c}0.19 * * * \\
(2.22)\end{array}$ \\
\hline Constant & $\begin{array}{c}0.55^{* * *} \\
(11.6)\end{array}$ & $\begin{array}{l}0.53 * * * \\
(11.5)\end{array}$ & $\begin{array}{l}0.51^{* * *} \\
(11.2)\end{array}$ & $\begin{array}{l}0.49 * * * \\
(10.40)\end{array}$ & $\begin{array}{c}0.44 * * * \\
(9.34)\end{array}$ & $\begin{array}{c}0.46^{* * * *} \\
(9.84)\end{array}$ & $\begin{array}{c}0.49 * * * \\
(9.54)\end{array}$ & $\begin{array}{c}0.54 * * * \\
(9.78)\end{array}$ & $\begin{array}{c}0.52^{* * *} \\
(9.64)\end{array}$ \\
\hline F-stat & $8.57 * * *$ & $8.41^{* * *}$ & $8.39 * * *$ & $8.23^{* * *}$ & $8.12^{* * *}$ & $8.06 * * *$ & $9.11^{* * *}$ & $9.19 * * *$ & $9.17^{* * *}$ \\
\hline $\begin{array}{l}\text { R-squ- } \\
\text { ared }\end{array}$ & 0.76 & 0.74 & 0.72 & 0.69 & 0.56 & 0.62 & 0.70 & 0.67 & 0.69 \\
\hline $\begin{array}{l}\text { Adj.R- } \\
\text { squared }\end{array}$ & 0.71 & 0.63 & 0.69 & 0.54 & 0.51 & 0.59 & 0.67 & 0.64 & 0.65 \\
\hline Nobs & 30 & 0 & 30 & 0 & 30 & 30 & 30 & 30 & 0 \\
\hline
\end{tabular}

Note: (a) Numbers in the parentheses are the values of t-statistics***indicates parametres are significant at 1per cent probability level; ** indicates parametres are significant at 5 per cent probability level; and $*$ indicates parametres are significant at 10 per cent probability level.

(b) $R$ is rainfall; $G C A$ is gross cropped area; $C l$ is cropping intensity; $G I A$ is the gross irrigated area; $F C$ is fertiliser consumption and $L R$ is literacy rate. 


\section{Conclusion and Policy Implications}

Changes in the cropping pattern are intended to give a wider choice in the production of a variety of crops in a given area so as to expand production of various crops and also to lessen risk. Area shifts and crop pattern changes can lead either to crop specialisation or to crop diversification. It is evident from the analysis that more than 75 per cent of GCA has been used for foodgrain cultivation in the State and cereal centred specialisation.A skewed distribution of area has been observed for cereal cultivation and a less proportion of area is used for other crops. Even though larger amount of land is used production and productivity of foodgrains are not satisfactory. Under non-foodgrains category vegetable production and productivity in the State is quite remarkable, though area used has remained low. Odisha ranks $4^{\text {th }}$ position as far as production of vegetables is concerned at national level (Government of Odisha, 2014). The per capita consumption of vegetables in the State is highest in the country. There is potentiality for growing all types of tropical, sub-tropical and temperate vegetables. Lack of awareness, poor rural infrastructure and poor marketing facilities are the major hindrances to expand the area under vegetables in Odisha. It is observed that there are variations in the share of area, production and productivity of major crop groups over the time period at the State level as well as across the physiographic zones.

As discussed earlier, the cropping pattern changes, however, are the outcomes of the interactive effect of many factors like resource related factors (irrigation, rainfall and soil fertility), technology related factors (seed, fertiliser, storage and processing), institutional and infrastructure related factors (farm size, extension, marketing systems, investment, output and input prices, government regulatory policies and research). Odisha agriculture has experienced the change in the relative importance of these factors over time (Table 9).

Table 9 : Changes in the Growth of Major Key Indicators of Odisha Agriculture (in percentage)

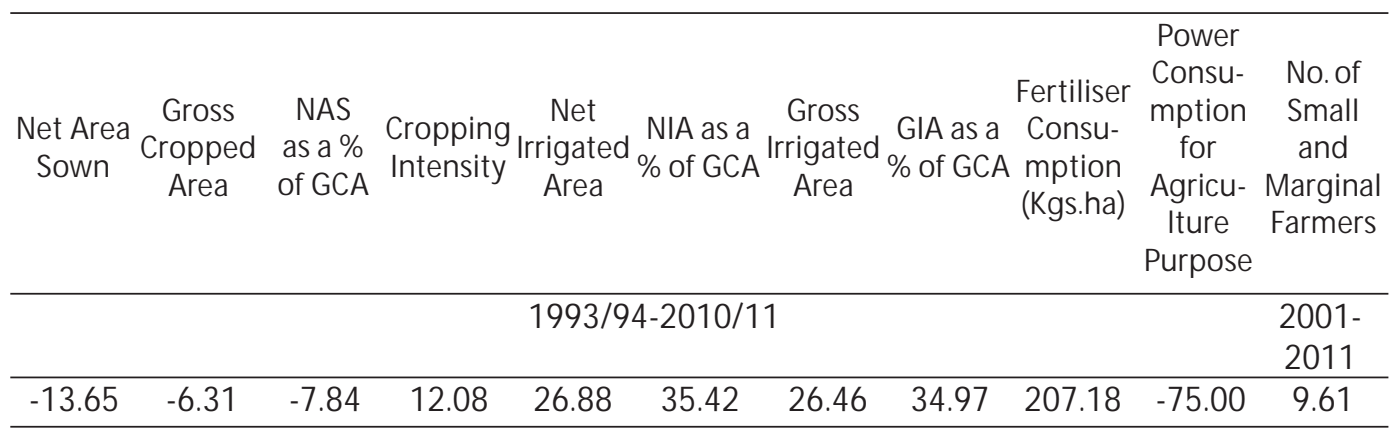

Source:From various reports of Odisha Agriculture Statistics, Directorate of Agriculture and Food Production, Government of Odisha.

Journal of Rural Development, Vol. 36, No. 1, January - March : 2017 
Agriculture in Odisha is increasingly getting influenced more and more by economic factors i.e., irrigation, fertilisers consumption, technology adoption and infrastructure. It is observed that both gross cropped area and net area sown have declined by 6.31 and 13.65 percent, respectively, during 1993/94-2010/11. Increasing diversion of agricultural land to non-agricultural uses due to industrialisation and urbanisation and rising trend of barren land appear alarming that led to decline in area under cultivation. The role played by the adverse weather conditions and the slow pace of expansion of irrigation cannot be ignored in this perspective. Furthermore, number of small and marginal farmers has also increased by a significant percentage (9.61) during 2001-2011, which led to low levels of risk taking capacity, technology adoption, farm mechanisation and fertiliser application, resulting in low levels of investment as also the low farm productivity. Along with these, growth of intensive cultivation is very slow in the State.

The slow growth of two important agricultural output diversifying inputs like irrigation and fertilisers are considered to be the most immediate and important determining factors responsible for slow change in the cropping pattern. Though fertiliser consumption has increased by 207 per cent the absolute amount of consumption per hectare is much lower than the national figure. Although net irrigated area and gross irrigated area has increased by 26.88 and 26.46 per cent respectively, a large part of the cultivated land depends on monsoon. The low level of consumption of power which is critical for mechanisation of agriculture indicates the lack of modernisation of the agriculture sector in the State. Percentage of power consumption for agricultural purposes declined by 75 over the time period. There has been a consistent drop in the share of agriculture sector to total power consumed in the State. The main reason ascribed for this decline is the lack of dedicated electric feeder ensuring consistent power supply for agricultural purpose especially to mega lift points. On the contrary, there has been a sharp rise in the use of power by industrial sector leading to an apparent drop in the share of power consumed by agriculture sector (Government of Odisha, 2014). As multiple demands for land increase, less land is devoted to agricultural sector. Therefore, intensive cultivation of available land seems to be a viable strategy for increasing the gross cropped area along with mechanisation and modernisation of agriculture. This is required for augmenting agricultural production in the State.

What is more, the reform initiatives undertaken in the context of ongoing agricultural liberalisation and globalisation policies are also going to further determine the crop composition both at the micro and macro levels. The policies, since the beginning of the 1990s, have had direct and indirect effects on farmers'welfare. The economic reforms did not include any specific package designed for agriculture. Rather, the presumption was that freeing agricultural markets and liberalising external trade in agricultural commodities 
would provide price incentives leading to enhanced investment and output in that sector, while broader trade liberalisation would shift inter-sectoral terms of trade in favour of agriculture. However, there are changes in patterns of government spending and financial measures which also necessarily affected the conditions of agriculture.

For a holistic development of agriculture and allied sectors, the State has initiated all round development of agriculture sector with a focus on increasing the production and productivity of different crops despite the aberrant weather conditions and limited resources. Some of the important schemes that are being implemented in the State such as National Food Security Mission (NFSM), Rashtriya Krishi Vikas Yojona (RKVY), Sustainable Development of Sugarcane based Cropping Systems, Agriculture Mechanisation under Work Plan, Integrated Schemes for Oilseeds, Pulses, Oilpalm \& Maize (ISOPOM), System of Rice Intensification (SRI),Technology Mission on Cotton, Technology Mission on Sugarcane, Jute Technology Mission, National Project on Management of Soil Health and
Fertility, e-Pest Surveillance, National Horticulture Mission, etc., which play vital role in making farming sustainable and obtain maximum return per rupee invested in the farm land. Besides, schemes on 'Capacity Building and Extension Reforms','Post-harvest Management of Agri-produce' and 'Establishment of Commercial Agri-enterprises' are also being implemented to supplement the development agenda. However, the neo-liberal economic reform strategy which involves fiscal policies of reducing expenditure on certain areas especially rural spending, trade liberalisation, financial liberalisation and privatisation of important areas of economic activity and service provision have adverse impact on agriculture and rural living conditions. To conclude, it may be stated that Odisha's agriculture has to go a long way to achieve crop diversification and balance in the inter-crop allocation of existing and additional areas to be brought under cultivation. To sustain and operationalise crop diversification in the State, institutional support, research and developmental support, and technological support are required. 


\section{References}

1 Alexandratos, N and Bruinsma,J (2012), “World Agriculture towards 2030/2050:The 2012 Revision”, ESA Working paper No. 12-03, Rome, FAO.

2 Bhalla, G. S and Singh, G (2009), "Economic Liberalisation and Indian Agriculture: A State-wise Analysis", Economic and Political Weekly, 54 (52):pp. 34-44.

3 Chand, R. (2001), "Emerging Trends and Issues in Public and Private Investments in Indian Agriculture: A State-wise Analysis", Indian Journal of Agricultural Economics, 56 (2): pp. 161-184.

4 Chand, R (2003), “Government Intervention in Food Grain Markets in the Changing Context",Policy Paper No. 19, National Centre for Agricultural Economics and Policy Research, New Delhi.

5 Government of Odisha (2012), "Economic Survey 2011-12,"Department of Economics and Statistics, Bhubaneswar, Odisha.

6 Government of Odisha (2014), “Agricultural Statistics Odisha, 2013-14," Department of Economics and Statistics, Bhubaneswar, Odisha.

7 Hazra, C.R (2001), "Crop Diversification in India”, in "Crop Diversification in the Asia-Pacific Region, Edited by Minas K. Papademetriou and Frank J. Dent, Food and Agriculture Organisation of the United Nations.

8 Joshi, P K, Pratap Singh Birthal and Nicholas Minot (2006), "Sources of Agricultural Growth in India: Role of Diversification towards High Value Crops", MTID Discussion Paper No. 98. Washington, D.C.: International Food Policy Research Institute.

9 Malthus,T.R (1798), “An Essay on the Principle of Population and A Summary View of the Principle of Population", Reprinted by Penguin Press, Harmondsworth.

10 Mishra, S (2009), "Poverty and Agrarian Distress in Odisha”,Working Paper No. WP-2009-006, Indira Gandhi Institute of Development Research, Mumbai, http://www.igidr.ac.in/pdf/publication/WP2009-006.pdf.

11 Mishra, S. N and Chand, R (1995), "Private and Public Capital Formation in Indian Agriculture: Comments on Complementarity Hypothesis and Others", Economic and Political Weekly, 30 (24): pp. A 64-79.

12 Mohanty, S. Pattanaik, F. and Patra. R N (2013), "Agricultural Diversification in Odisha During Post Reform Period", Agricultural Situation in India, 70 (6): p. 5-14

13 Rahman, S (2009), "Whether Crop Diversification is a Desired Strategy for Agricultural Growth in Bangladesh?" Food Policy, 34 (4): pp. 340-349.

14 Rao,V.M (1996), “Agricultural Develo pment with a Human Face”,Economic and Political Weekly, 31(26): pp. A52 -62.

15 Ruthenberg, H (1980), "Farming Systems in the Tropics", Clarendon Press, Oxford.

16 Vyas,VS (2001), “Agriculture:Second Round of Economic Reforms”,Economic and Political Weekly, 36 (14):pp. 829-36.

17 Vyas, V.S (1996), “Diversification in Agriculture: Concept, Rationale and Approaches”, Indian Journal of Agricultural Economics, 51 (4): pp. 636-643.

18 Weinberger, K. and Lumpkin, T (2007),,,Diversification into Horticulture and Poverty Reduction: A Research Agenda", World Development, 35(8): pp.1464-1480. 


\section{ANNEXURE}

Table A1: District-wise Area, Yield Rate \& Production of All Crop Groups during 1993-94 in Odisha

\begin{tabular}{|c|c|c|c|c|}
\hline S. No. & DISTRICT & $A$ & $Y$ & $P$ \\
\hline 1 & Balasore & 433.95 & 2185.00 & 1124.30 \\
\hline 2 & Bhadrak & 265.61 & 2181.15 & 524.08 \\
\hline 3 & Bolangir & 472.22 & 1831.39 & 729.91 \\
\hline 4 & Sonepur & 184.73 & 1966.51 & 341.41 \\
\hline 5 & Cuttack & 371.21 & 2290.05 & 925.25 \\
\hline 6 & Jagatsinghpur & 225.25 & 2086.16 & 463.42 \\
\hline 7 & Jajpur & 316.11 & 2159.37 & 597.86 \\
\hline 8 & Kendrapara & 293.36 & 2135.75 & 589.81 \\
\hline 9 & Dhenkanal & 336.44 & 2284.30 & 605.12 \\
\hline 10 & Angul & 331.55 & 2247.99 & 570.41 \\
\hline 11 & Ganjam & 755.29 & 1858.51 & 1247.83 \\
\hline 12 & Gajapati & 121.97 & 1767.74 & 175.21 \\
\hline 13 & Kalahandi & 568.71 & 1745.83 & 700.01 \\
\hline 14 & Nuapara & 246.64 & 1744.07 & 297.99 \\
\hline 15 & Keonjhar & 412.24 & 1664.57 & 642.20 \\
\hline 16 & Koraput & 415.11 & 1971.68 & 671.73 \\
\hline 17 & Malkangiri & 194.43 & 1898.09 & 274.81 \\
\hline 18 & Nawarangpur & 267.28 & 1803.01 & 428.87 \\
\hline 19 & Rayagada & 268.35 & 1592.36 & 321.57 \\
\hline 20 & Mayurbhanj & 544.36 & 2216.81 & 1118.33 \\
\hline 21 & Kandhamal & 227.74 & 2027.36 & 310.51 \\
\hline 22 & Boudh & 124.79 & 1974.19 & 163.07 \\
\hline 23 & Puri & 296.78 & 1659.71 & 541.41 \\
\hline 24 & Khurda & 225.15 & 2312.41 & 470.32 \\
\hline 25 & Nayagarh & 209.27 & 2397.67 & 336.34 \\
\hline 26 & Sambalpur & 266.13 & 2633.66 & 583.68 \\
\hline 27 & Bargarh & 487.39 & 1981.80 & 986.46 \\
\hline 28 & Deogarh & 92.80 & 2196.14 & 172.37 \\
\hline 29 & Jharsuguda & 103.49 & 2590.50 & 254.54 \\
\hline 30 & Sundargarh & 404.23 & 1650.61 & 596.01 \\
\hline
\end{tabular}

Note: 1:- A = Area in '000 hect.; Y=Yield in Kgs/hects. ; P=Production in '000MTs.

Note: 2:- All Crop Group includes; Cereals, Pulses, Oilseeds, Fibers, Vegetables, Condiments and Spices. Source: Odisha Agriculture Statistics published by Directorate of Agriculture and Food Production, Government of Odisha.

Journal of Rural Development, Vol. 36, No. 1, January - March : 2017 


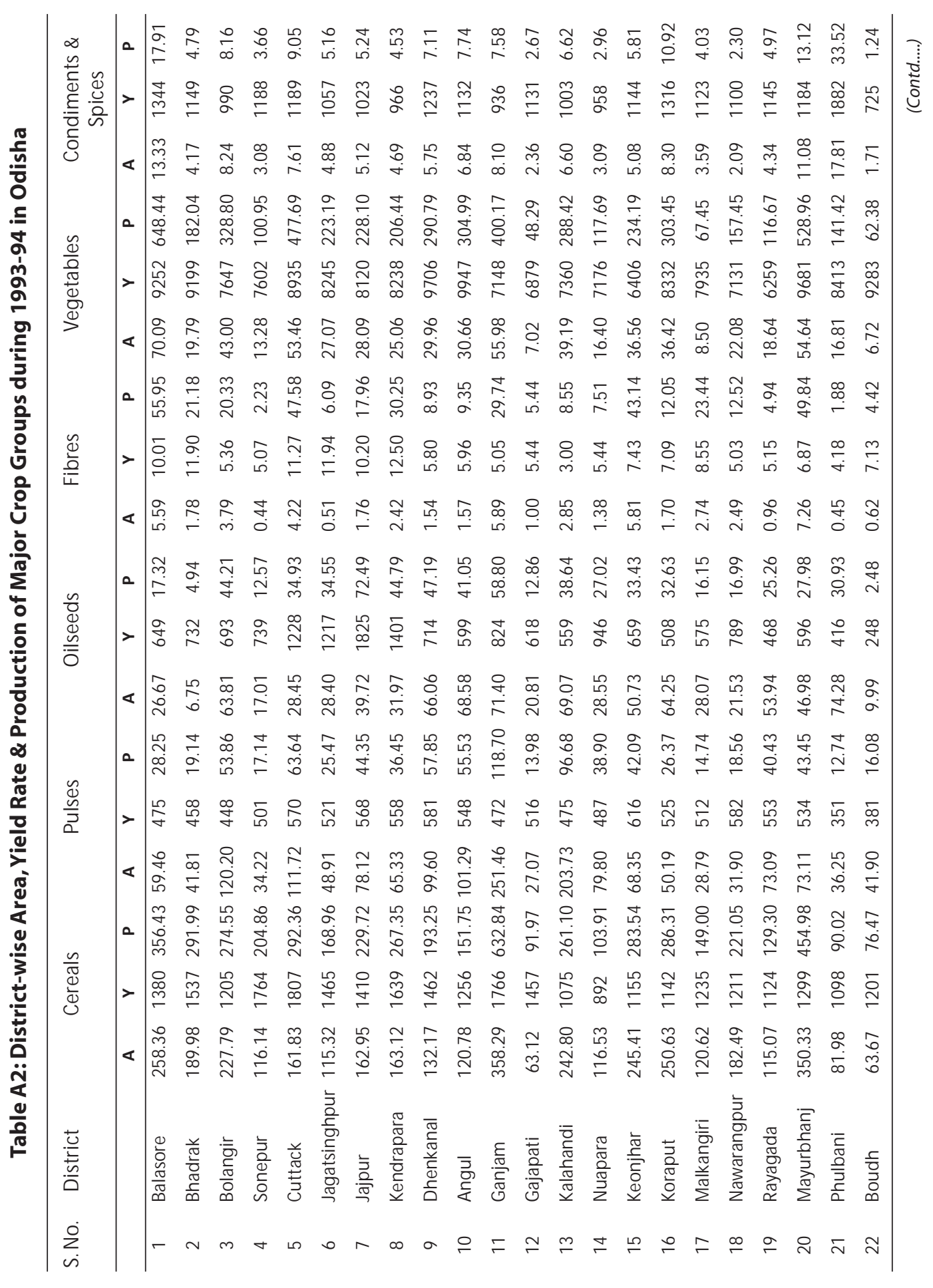

Journal of Rural Development, Vol. 36, No. 1, January - March :2017 


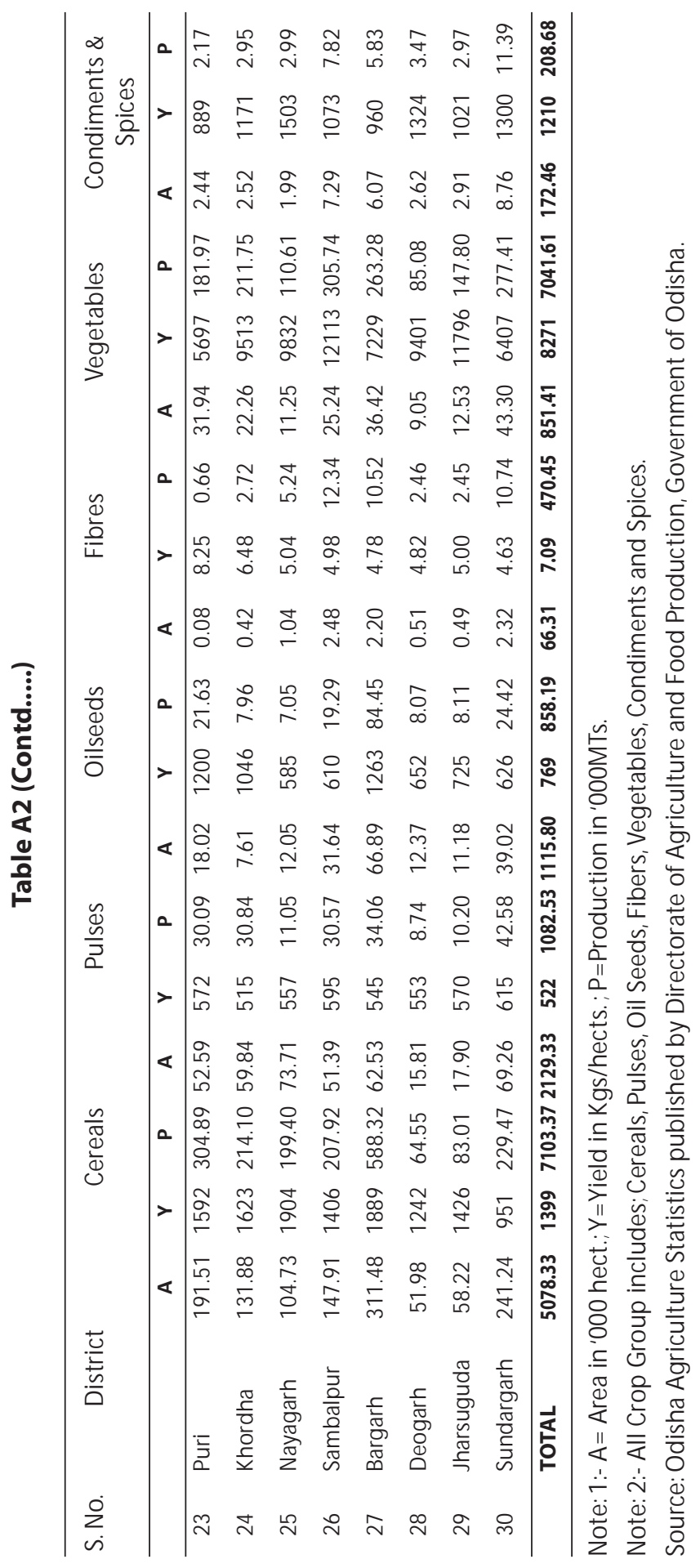

Journal of Rural Development, Vol. 36, No. 1, January - March : 2017 
Table A3: District-wise Area, Yield Rate \& Production of All Crop Groups during 2001-02 in Odisha

\begin{tabular}{|c|c|c|c|c|}
\hline S. No. & DISTRICT & $A$ & $\mathrm{Y}$ & $P$ \\
\hline 1 & Balasore & 330.00 & 2894.33 & 810.30 \\
\hline 2 & Bhadrak & 202.00 & 3055.67 & 522.16 \\
\hline 3 & Bolangir & 421.00 & 2542.83 & 669.30 \\
\hline 4 & Sonepur & 172.00 & 2702.83 & 481.64 \\
\hline 5 & Cuttack & 290.00 & 2872.33 & 546.05 \\
\hline 6 & Jagatsinghpur & 178.00 & 3132.67 & 365.71 \\
\hline 7 & Jajpur & 258.00 & 3187.67 & 532.31 \\
\hline 8 & Kendrapara & 230.00 & 2865.33 & 509.21 \\
\hline 9 & Dhenkanal & 255.00 & 2675.67 & 556.65 \\
\hline 10 & Angul & 292.00 & 2580.33 & 477.72 \\
\hline 11 & Ganjam & 692.00 & 2811.33 & 1328.30 \\
\hline 12 & Gajapati & 122.00 & 2814.17 & 310.08 \\
\hline 13 & Kalahandi & 520.00 & 2655.33 & 753.73 \\
\hline 14 & Nuapara & 255.00 & 2406.67 & 398.62 \\
\hline 15 & Keonjhar & 409.00 & 2734.17 & 880.83 \\
\hline 16 & Koraput & 368.00 & 2393.00 & 599.02 \\
\hline 17 & Malkangiri & 215.00 & 2579.17 & 390.97 \\
\hline 18 & Nawarangpur & 279.00 & 2430.67 & 510.55 \\
\hline 19 & Rayagada & 237.00 & 2436.00 & 400.76 \\
\hline 20 & Mayurbhanj & 488.00 & 2862.33 & 1063.55 \\
\hline 21 & Kandhamal & 160.00 & 2568.83 & 346.89 \\
\hline 22 & Boudh & 120.00 & 2556.83 & 272.38 \\
\hline 23 & Puri & 232.00 & 2817.00 & 553.43 \\
\hline 24 & Khurda & 212.00 & 2645.17 & 444.23 \\
\hline 25 & Nayagarh & 215.00 & 2864.67 & 314.08 \\
\hline 26 & Sambalpur & 263.00 & 2719.17 & 589.95 \\
\hline 27 & Bargarh & 440.00 & 2768.50 & 879.46 \\
\hline 28 & Deogarh & 106.00 & 2738.67 & 245.16 \\
\hline 29 & J harsuguda & 115.00 & 2701.50 & 302.23 \\
\hline 30 & Sundargarh & 364.00 & 2801.50 & 599.43 \\
\hline
\end{tabular}

Note: 1 :- $A=$ Area in '000 hect.; Y=Yield in Kgs/hects. ; P=Production in '000MTs.

Note: 2:- All Crop Group includes; Cereals, Pulses, Oilseeds, Fibers, Vegetables, Condiments and Spices.

Source: Odisha Agriculture Statistics published by Directorate of Agriculture and Food Production, Government of Odisha.

Journal of Rural Development, Vol. 36, No. 1, January - March :2017 


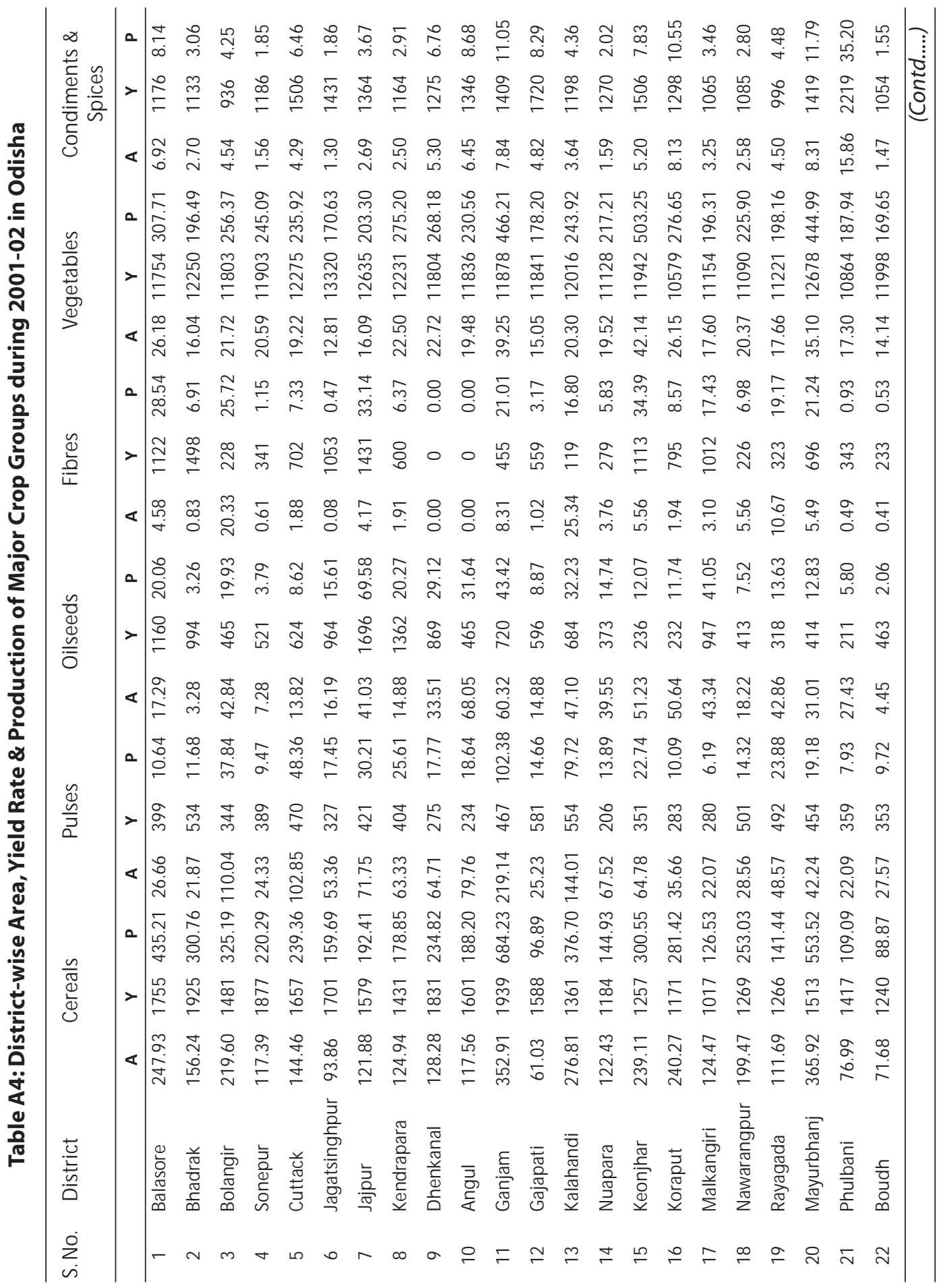

Journal of Rural Development, Vol. 36, No. 1, January - March :2017 


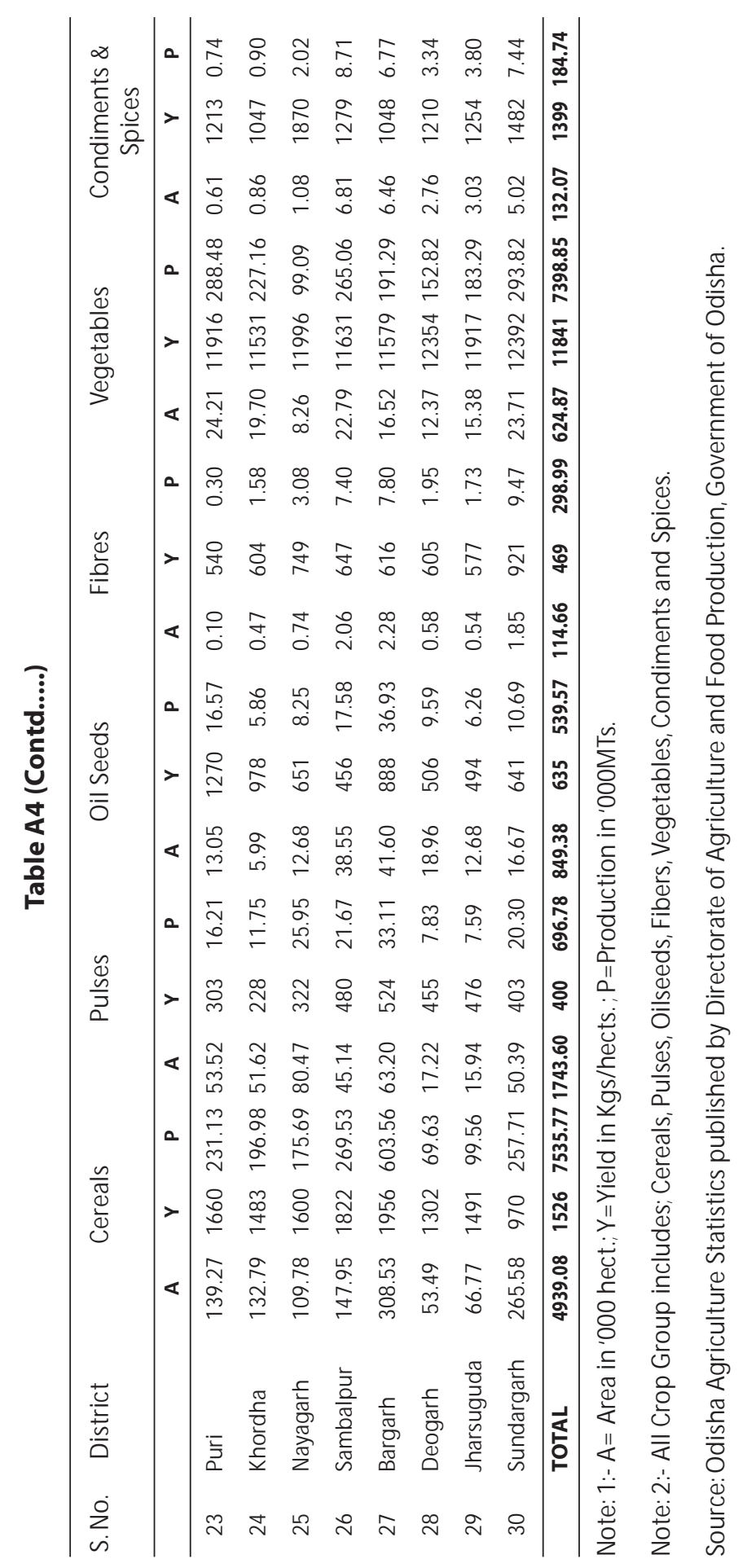

Journal of Rural Development, Vol. 36, No. 1, January - March : 2017 
Table A5: District-wise Area, Yield Rate \& Production of All Crop Groups during 2010-11 in Odisha

\begin{tabular}{|c|c|c|c|c|}
\hline S. No. & DISTRICT & $A$ & $Y$ & $P$ \\
\hline 1 & Balasore & 320.95 & 3003.17 & 846.87 \\
\hline 2 & Bhadrak & 208.99 & 3379.00 & 638.63 \\
\hline 3 & Bolangir & 470.59 & 3058.17 & 1147.96 \\
\hline 4 & Sonepur & 206.48 & 2896.83 & 608.79 \\
\hline 5 & Cuttack & 305.76 & 3695.67 & 745.45 \\
\hline 6 & Jagatsinghpur & 179.60 & 3594.50 & 469.45 \\
\hline 7 & Jajpur & 260.65 & 3206.83 & 585.24 \\
\hline 8 & Kendrapara & 256.75 & 3627.33 & 592.54 \\
\hline 9 & Dhenkanal & 234.44 & 3253.83 & 582.51 \\
\hline 10 & Angul & 283.44 & 3058.33 & 500.05 \\
\hline 11 & Ganjam & 689.83 & 2598.33 & 1130.02 \\
\hline 12 & Gajapati & 137.11 & 2915.00 & 374.69 \\
\hline 13 & Kalahandi & 590.17 & 3414.17 & 1314.42 \\
\hline 14 & Nuapara & 262.90 & 2779.17 & 434.34 \\
\hline 15 & Keonjhar & 391.43 & 3266.67 & 1082.11 \\
\hline 16 & Koraput & 372.78 & 3569.67 & 820.17 \\
\hline 17 & Malkangiri & 216.17 & 3072.00 & 513.50 \\
\hline 18 & Nawarangpur & 271.62 & 3003.83 & 794.10 \\
\hline 19 & Rayagada & 237.51 & 3187.50 & 562.87 \\
\hline 20 & Mayurbhanj & 424.16 & 3138.67 & 807.46 \\
\hline 21 & Kandhamal & 171.33 & 4286.50 & 604.22 \\
\hline 22 & Boudh & 130.94 & 3167.33 & 348.13 \\
\hline 23 & Puri & 256.65 & 3188.33 & 524.78 \\
\hline 24 & Khurda & 192.61 & 3487.67 & 546.47 \\
\hline 25 & Nayagarh & 216.37 & 3595.50 & 442.82 \\
\hline 26 & Sambalpur & 264.50 & 2675.00 & 476.15 \\
\hline 27 & Bargarh & 441.67 & 2894.83 & 931.20 \\
\hline 28 & Deogarh & 96.48 & 2736.67 & 172.37 \\
\hline 29 & J harsuguda & 94.75 & 2822.50 & 129.79 \\
\hline 30 & Sundargarh & 371.03 & 2884.33 & 640.21 \\
\hline
\end{tabular}

Note: 1:- $A=$ Area in '000 hect.; $Y=Y$ ield in Kgs/hects. ; $P=$ Production in '000MTs.

Note: 2:- All Crop Group includes; Cereals, Pulses, Oilseeds, Fibers, Vegetables, Condiments and Spices.

Source: Odisha Agriculture Statistics published by Directorate of Agriculture and Food Production, Government of Odisha.

Journal of Rural Development, Vol. 36, No. 1, January - March :2017 


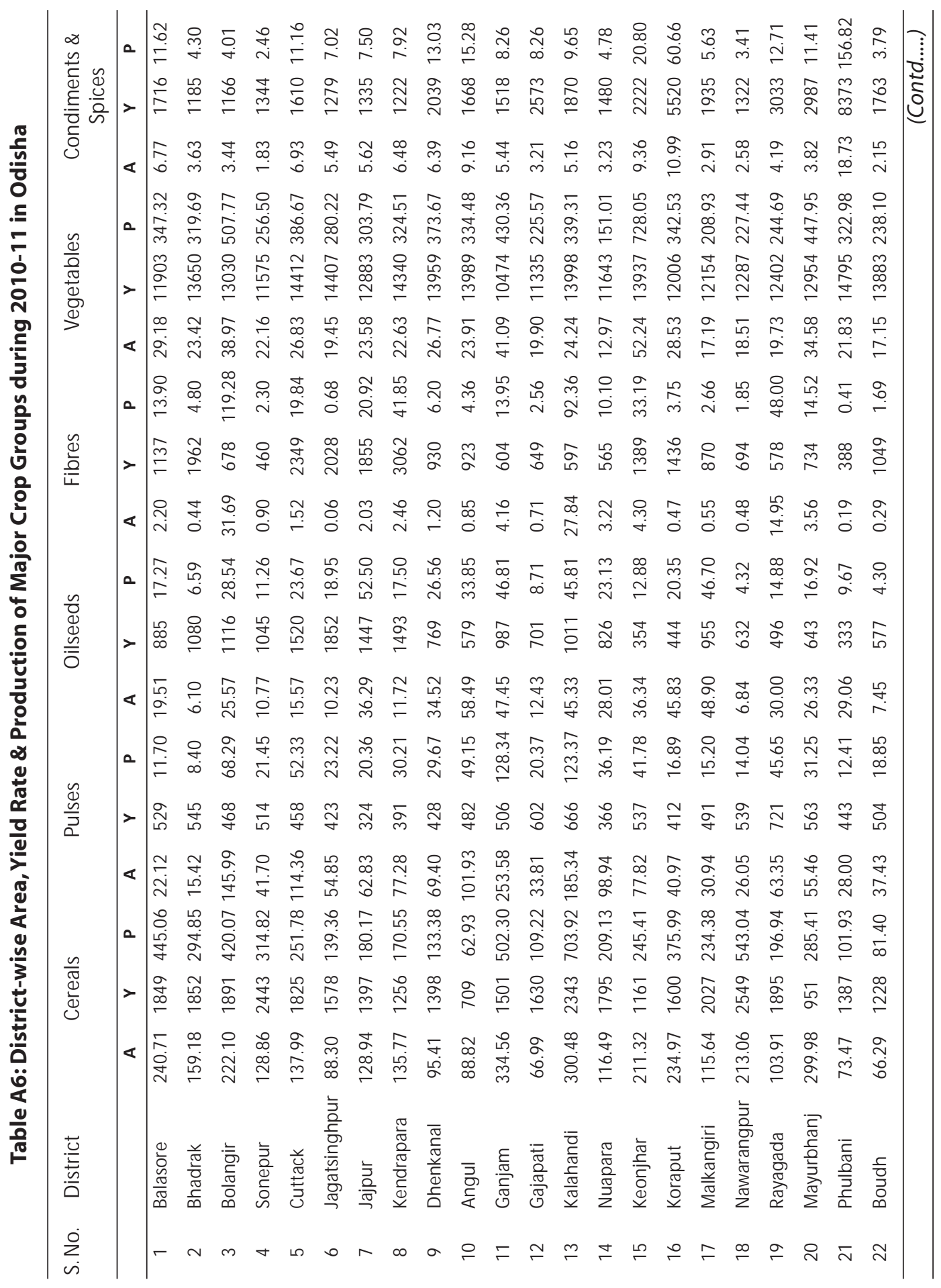

Journal of Rural Development, Vol. 36, No. 1, January - March :2017 


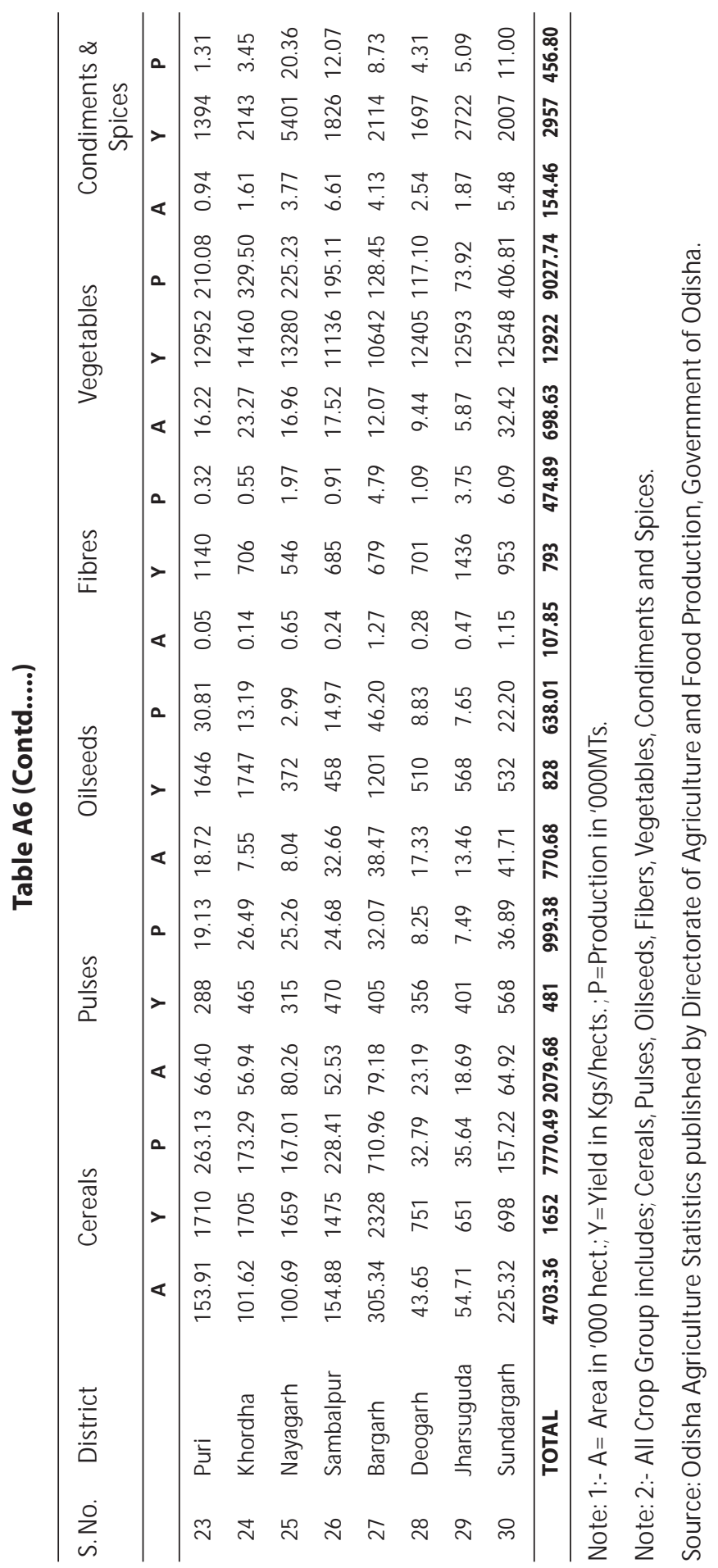

Journal of Rural Development, Vol. 36, No. 1, January - March : 2017 
Table A7: Performance of Major Key Indicators of Odisha Agriculture during 1993/94-2010/11 (Area in '000 hectare)

\begin{tabular}{|c|c|c|c|c|}
\hline S. No. & DISTRICT & $A$ & $Y$ & $P$ \\
\hline 1 & Balasore & 320.95 & 3003.17 & 846.87 \\
\hline 2 & Bhadrak & 208.99 & 3379.00 & 638.63 \\
\hline 3 & Bolangir & 470.59 & 3058.17 & 1147.96 \\
\hline 4 & Sonepur & 206.48 & 2896.83 & 608.79 \\
\hline 5 & Cuttack & 305.76 & 3695.67 & 745.45 \\
\hline 6 & Jagatsinghpur & 179.60 & 3594.50 & 469.45 \\
\hline 7 & Jajpur & 260.65 & 3206.83 & 585.24 \\
\hline 8 & Kendrapara & 256.75 & 3627.33 & 592.54 \\
\hline 9 & Dhenkanal & 234.44 & 3253.83 & 582.51 \\
\hline 10 & Angul & 283.44 & 3058.33 & 500.05 \\
\hline 11 & Ganjam & 689.83 & 2598.33 & 1130.02 \\
\hline 12 & Gajapati & 137.11 & 2915.00 & 374.69 \\
\hline 13 & Kalahandi & 590.17 & 3414.17 & 1314.42 \\
\hline 14 & Nuapara & 262.90 & 2779.17 & 434.34 \\
\hline 15 & Keonjhar & 391.43 & 3266.67 & 1082.11 \\
\hline 16 & Koraput & 372.78 & 3569.67 & 820.17 \\
\hline 17 & Malkangiri & 216.17 & 3072.00 & 513.50 \\
\hline 18 & Nawarangpur & 271.62 & 3003.83 & 794.10 \\
\hline 19 & Rayagada & 237.51 & 3187.50 & 562.87 \\
\hline 20 & Mayurbhanj & 424.16 & 3138.67 & 807.46 \\
\hline 21 & Kandhamal & 171.33 & 4286.50 & 604.22 \\
\hline 22 & Boudh & 130.94 & 3167.33 & 348.13 \\
\hline 23 & Puri & 256.65 & 3188.33 & 524.78 \\
\hline 24 & Khurda & 192.61 & 3487.67 & 546.47 \\
\hline 25 & Nayagarh & 216.37 & 3595.50 & 442.82 \\
\hline 26 & Sambalpur & 264.50 & 2675.00 & 476.15 \\
\hline 27 & Bargarh & 441.67 & 2894.83 & 931.20 \\
\hline 28 & Deogarh & 96.48 & 2736.67 & 172.37 \\
\hline 29 & J harsuguda & 94.75 & 2822.50 & 129.79 \\
\hline 30 & Sundargarh & 371.03 & 2884.33 & 640.21 \\
\hline
\end{tabular}

Note: 1:- $\mathrm{A}=$ Area in '000 hect.; Y=Yield in Kgs/hects.; P=Production in '000MTs.

Note: 2:- All Crop Group includes; Cereals, Pulses, Oilseeds, Fibers, Vegetables, Condiments and Spices.

Source: Odisha Agriculture Statistics published by Directorate of Agriculture and Food Production, Government of Odisha.

Journal of Rural Development, Vol. 36, No. 1, January - March :2017 


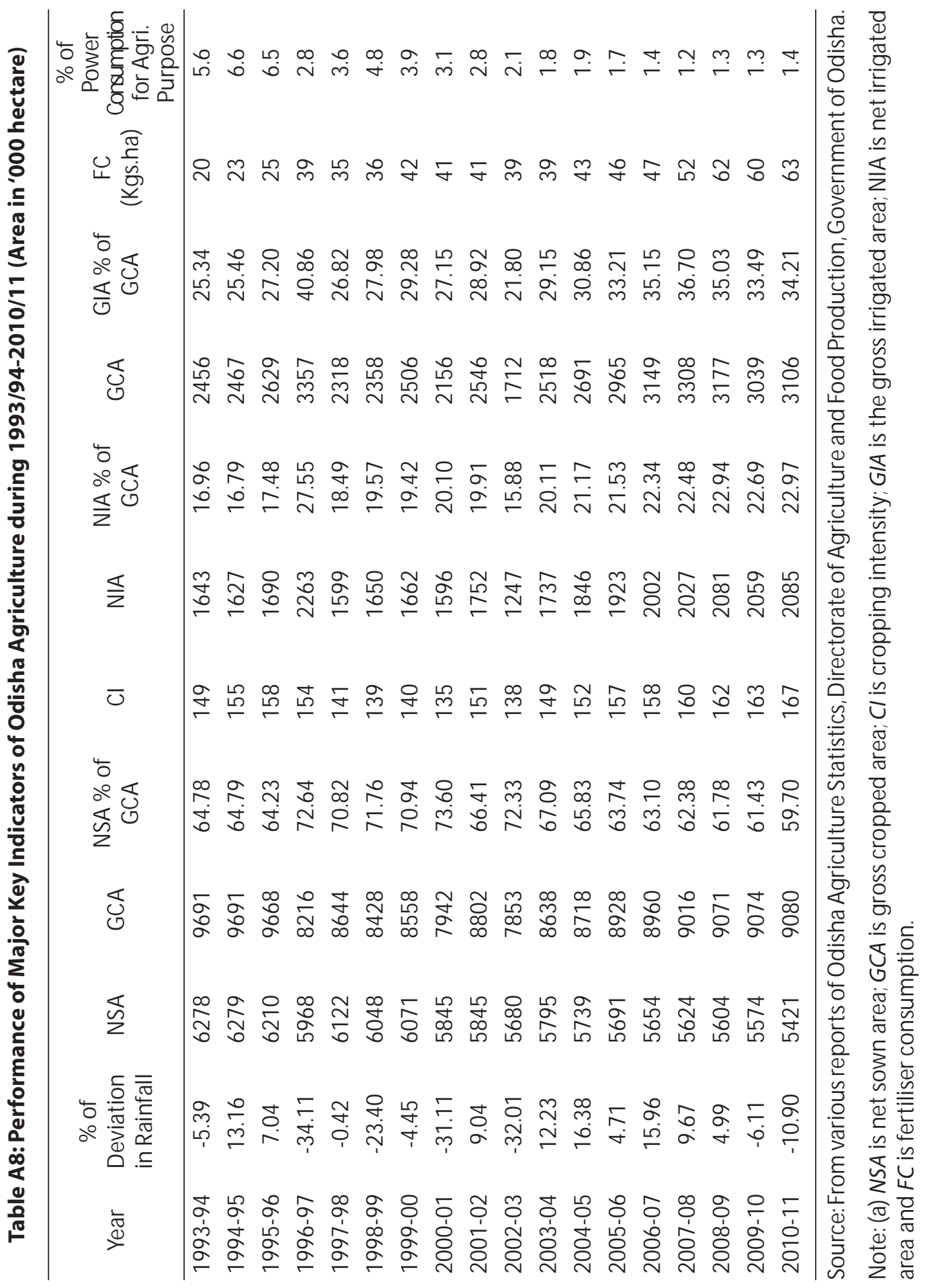

Journal of Rural Development, Vol. 36, No. 1, January - March :2017 